Portland State University

PDXScholar

$5-18-1984$

\title{
Early Childhood Education and Compensatory Education in the Portland, Oregon, Public Schools, 1965-1984
}

Dolores Jean Robinett Pappas

Portland State University

Follow this and additional works at: https://pdxscholar.library.pdx.edu/open_access_etds

Part of the Early Childhood Education Commons

Let us know how access to this document benefits you.

\section{Recommended Citation}

Pappas, Dolores Jean Robinett, "Early Childhood Education and Compensatory Education in the Portland, Oregon, Public Schools, 1965-1984" (1984). Dissertations and Theses. Paper 3419.

https://doi.org/10.15760/etd.5298

This Thesis is brought to you for free and open access. It has been accepted for inclusion in Dissertations and Theses by an authorized administrator of PDXScholar. Please contact us if we can make this document more accessible: pdxscholar@pdx.edu. 
AN ABSTRACT OF THE THESIS OF Dolores Jean (Robinett) Pappas for the Master of Science in Education with an emphasis in Early Childhood Education presented May 18, 1984.

Title: Early Childhood Education and Compensatory Education in the Portland, Oregon, Public Schools: 1965-1984

APPROVED BY MEMBERS OF THE THESIS COMMITTEE

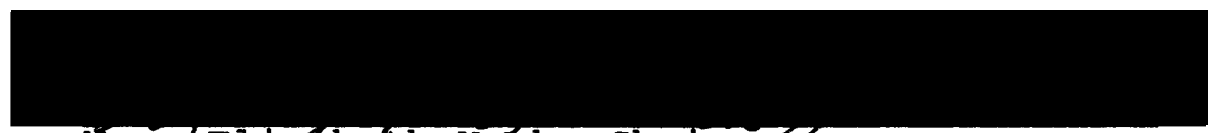

Maryclizabeth York, Chairperson
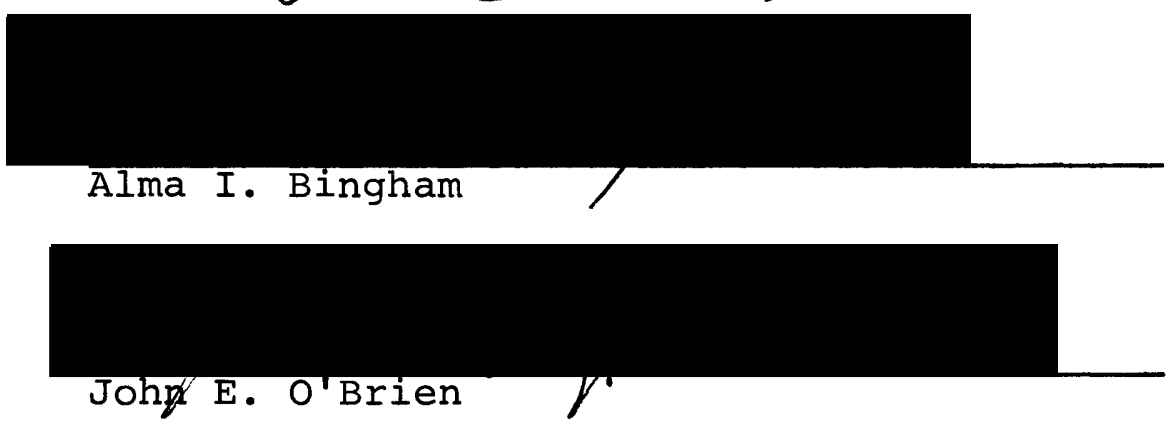

This investigation had the dual purpose of exploring, in historical perspectives, the academic discipline known as Early Childhood Education and the use of Early Childhood Education as a vehicle for compensatory education in the Portland Public Schools from 1965-1984. 
Two questions were asked:

1) How have the study and teaching of young children evolved, and what effect did the massive funding by the federal and state government in the 1960's and 1970's have on the redefinition of the discipline known as Early Childhood Education?

2) How has Portland Public School District 1 utilized the discipline known as Early Childhood Education during the period from 1965 to the present to meet the needs of the culturally disadvantaged in the context of desegregation/integration.

The study involved a two-pronged literature survey utilizing library resources, the staff and facilities of Portland Public School District $I$ and the Archives of the City of Portland. Interviews were also conducted.

The historical material describing the evolution of Early Childhood Education (Chapter II) and the early history of the Portland Public Schools (Chapter IV) stand chronologically as discrete units.

Chapter III provides information concerning the passage of the legislation and the funding which provided for the compensatory education programs of the 1960's and '70's. This chapter brings into convergence Chapters II and IV. 
The analysis of the data gathered, Chapter V, provides insight into the strengths and weaknesses of Early Childhood Education as an academic discipline. It also provides insight into the Portland Public School District 1 program, which tends to minimize the weaknesses and utilize the strengths for a valid Early Childhood Education program. 
EARLY CHILDHOOD EDUCATION AND COMPENSATORY EDUCATION IN THE PORTLAND, OREGON, PUBLIC SCHOOLS: 1965-1984

by

DOLORES JEAN (ROBINETT) PAPPAS

A thesis submitted in partial fulfillment of the requirements for the degree of

\author{
MASTER OF SCIENCE \\ in \\ EDUCATION \\ with an emphasis in \\ EARLY CHILDHOOD EDUCATION
}

Portland State University

1984 
TO THE OFFICE OF GRADUATE STUDIES AND RESEARCH

The members of the Committee approve the thesis of Dolores Jean (Robinett) Pappas presented May 18, 1984.

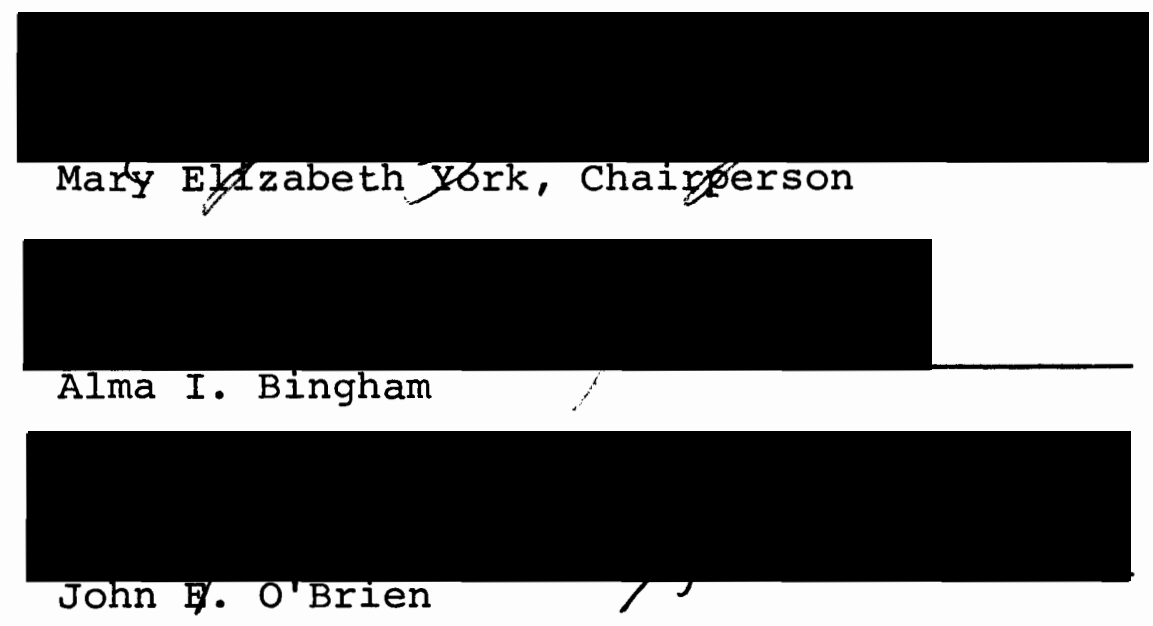

APPROVED :

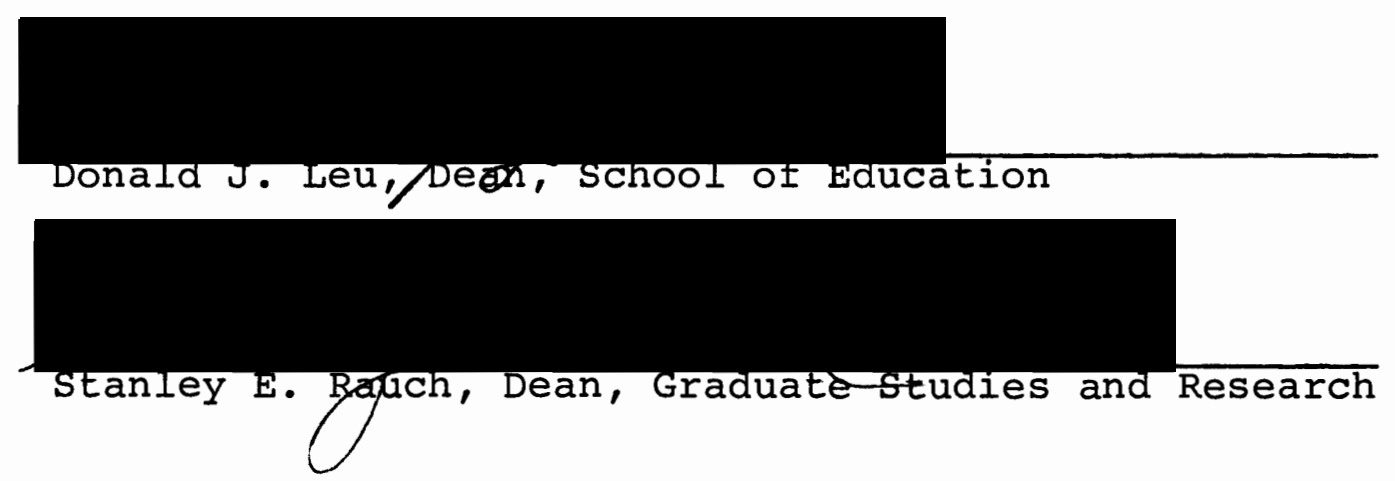




\section{ACKNOWLEDGEMENTS}

My deepest gratitude to my advisor Dr. Mary Elizabeth York, whose advocacy of quality lives for young children has been an inspiration. To Dr. Alma Bingham of my committee, sincere thanks.

Thanks to Karen Welch and those of the staff of the Portland Public Schools who gave so freely of their time and knowledge.

To all of those who held the Torch high while this paper was being written, you can never know what your kindnesses have meant to me. I wish to thank, especially, Paul Pollock for extending thoughtfulness and consideration far beyond what might be expected in the workplace. For Janella Flatt and Ken Hendrickson, those steady friends and fellow workers, my thanks for the ease of mind that knowing everything was under control at crucial moments.

Cindy and Laura, my love--and thanks for your nimble fingers. Tom, thanks for your concern for the missing page 4 .

Finally, to Dean, thank you for teaching me what love and commitment really mean. 
DEDICATION

To

William F. and Frances A. Robinett 


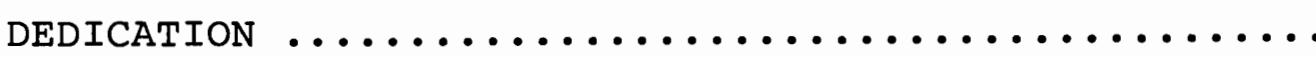

ACKNOWLEDGEMENTS $\ldots \ldots \ldots \ldots \ldots \ldots \ldots \ldots \ldots$ iv

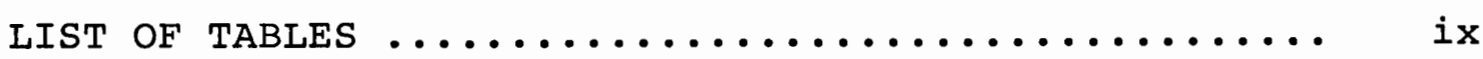

CHAPTER I : INTRODUCTION $\ldots \ldots \ldots \ldots \ldots \ldots \ldots \ldots \ldots \ldots$

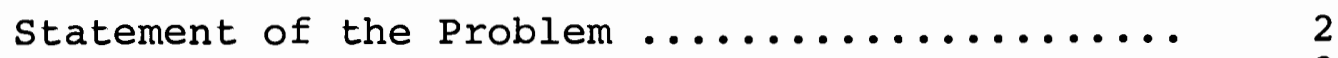

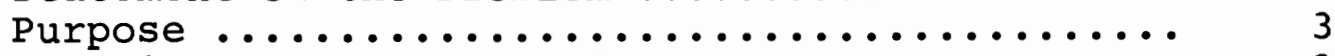

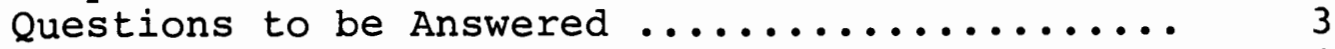

Procedure .......................... 4

Collection of Source Materials ........ 4

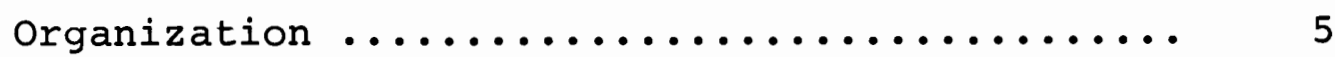

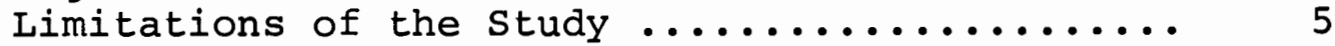

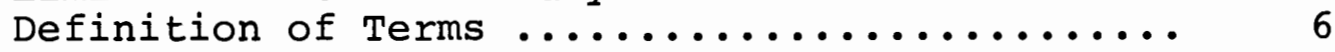

CHAPTER II: EARLY CHILDHOOD EDUCATION: A BRIEF

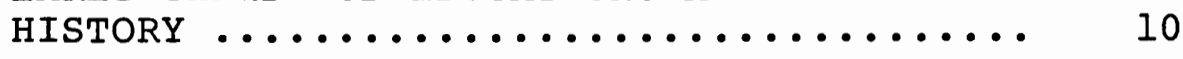

Themes in the Development of Early Childhood

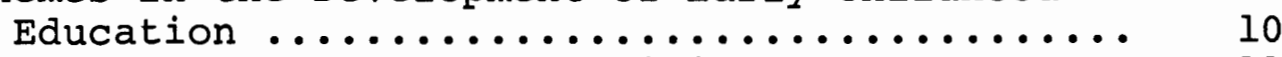

Pioneer Theorists and Practitioners ......... 11

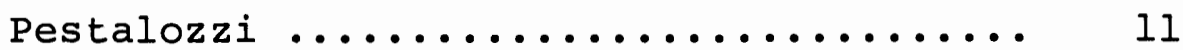

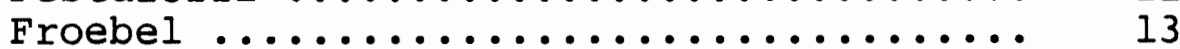

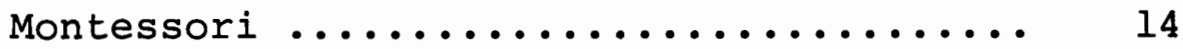

The MacMillan Sisters--The Rise of the Nursery School .............. 15

Early American Kindergartens ............ 16

Religious and Philanthropic Influences .. 16

Transfer to Public Schools ........... 18

Training of Teachers .................... 19

Philosophical Differences of Opinion .... 19

The Multidisciplinary Aspect of Early

Childhood Education ............... 20

Impact on the Public Schools .......... 20

Association of Early Childhood Educators

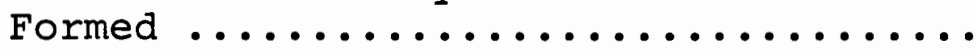


Page

The Child study Movement .................. 24

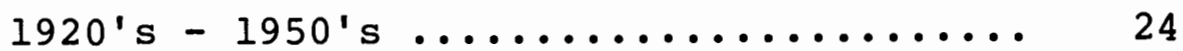

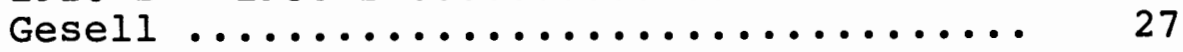

Cognitive Psychologists .................. 27

Move Toward Emphasis on Cognitive

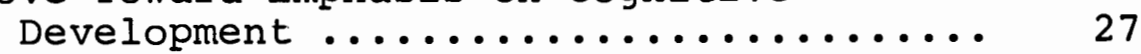

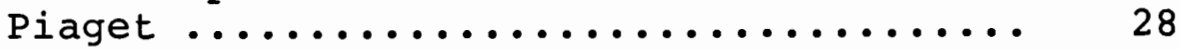

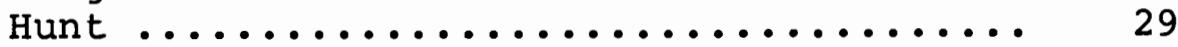

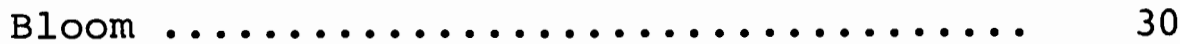

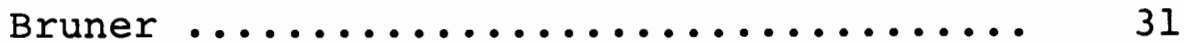

The Rise of Contemporary Education .......... 31

Defining and Redefining Early Childhood

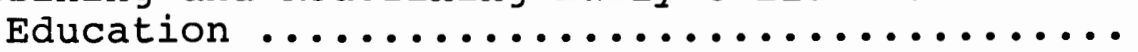

The California Early Childhood Education

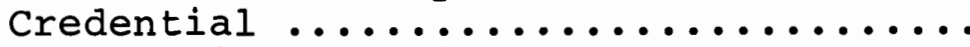

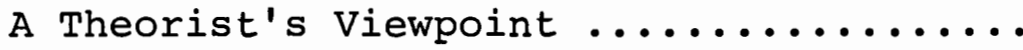

Two Innovative Programs in the Public Schools . 38

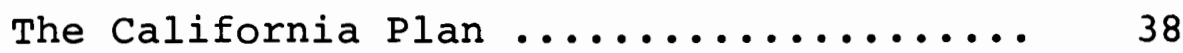

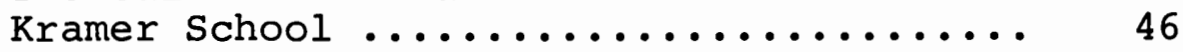

Early Childhood Education in the '80's ....... 54

CHAPTER III: RESEARCH AND PROGRAM FUNDING

$(1965-1984) \ldots \ldots \ldots \ldots \ldots \ldots \ldots \ldots \ldots$

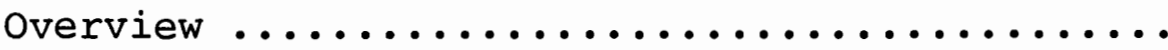

Elementary and Secondary Education Act .......

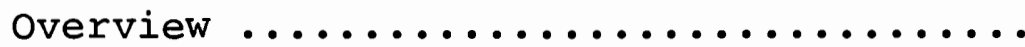

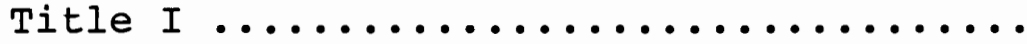

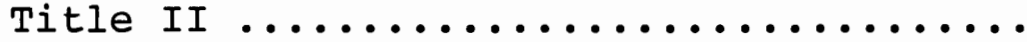

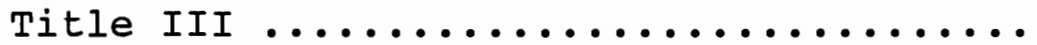

Title IV .........................

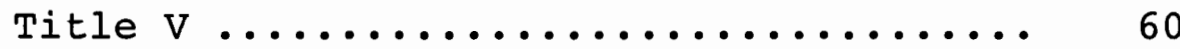

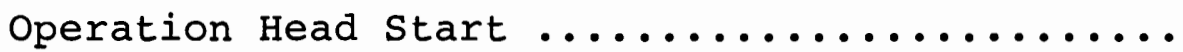

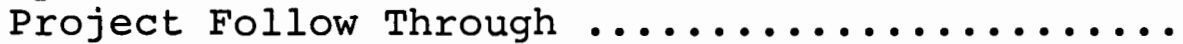

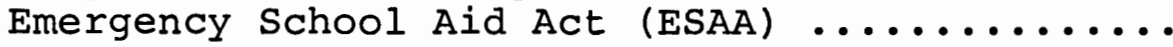

Equal Education Opportunities Act (EEOA) ......

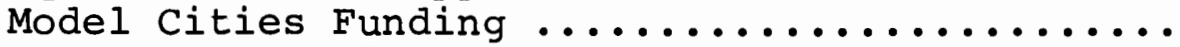


Page

CHAPTER IV: THE PORTLAND PUBLIC SCHOOLS ........... 65

History from $1851-1964 \ldots \ldots \ldots \ldots \ldots \ldots \ldots$

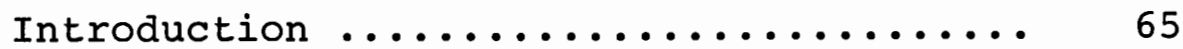

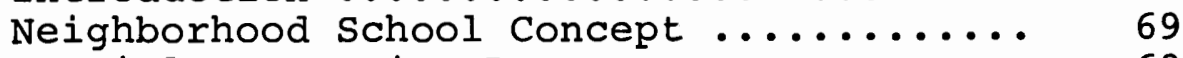

Special Supportive Programs ........... 69

Portland Citizens Committee on Racial

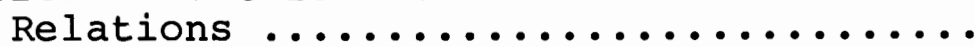

72

Committee on Race and Education (The Schwab

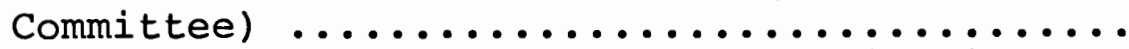

"Race and Equal Educational Opportunity in

Portland's Public Schools" (The Schwab

Report) ..........................

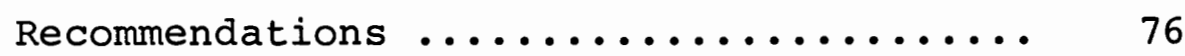

Model Schools Program .................... 76

Designated Elementary Schools ......... 76

The Voluntary Administrative Transfer

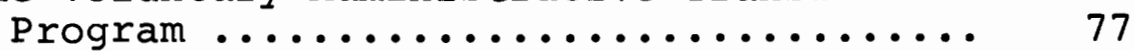

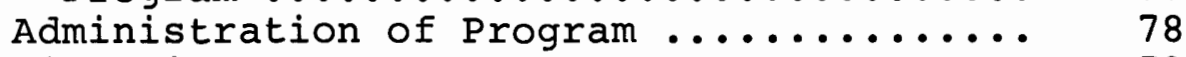

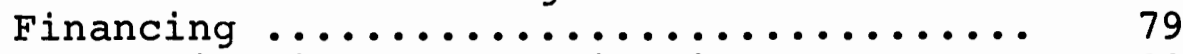

Reorganization of the District ......... 80

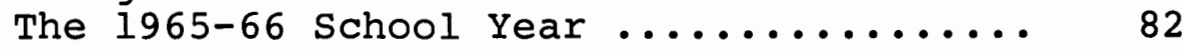

1967--The Early Childhood Education

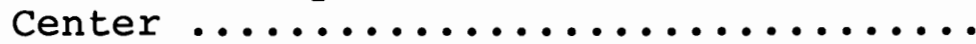

1968--Report on the Model Schools

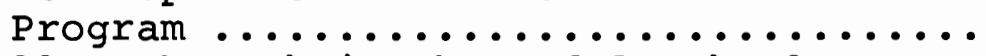

Follow Through in the Model Schools

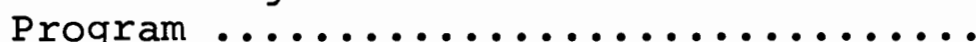

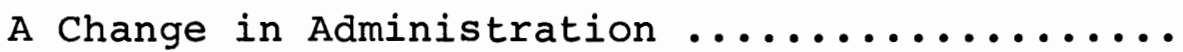

Robert Blanchard and the Portland Schools

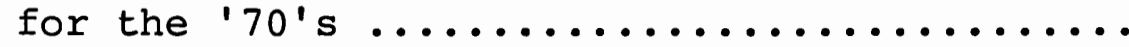

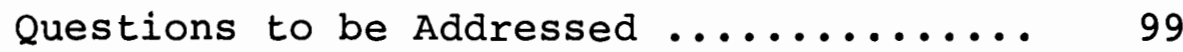

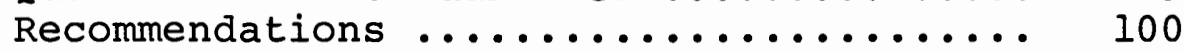

Early Childhood Education Centers ....... 102

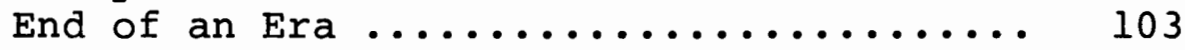


viii

Page

The Community Coalition for School

Integration ....................... 104

Equity for the '80's .............. 104

The Matthew Prophet Superintendency (1982-

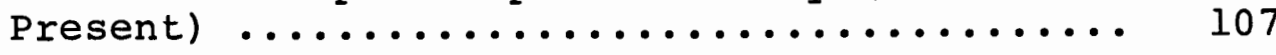

CHAPTER V: CONCLUSIONS AND RECOMMENDATIONS FOR

FURTHER STUDY .................. 110

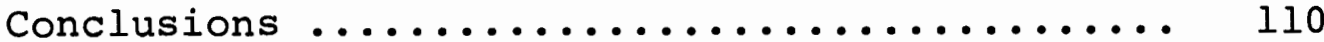

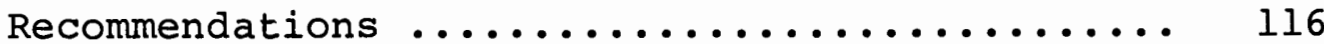

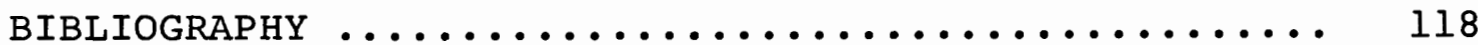

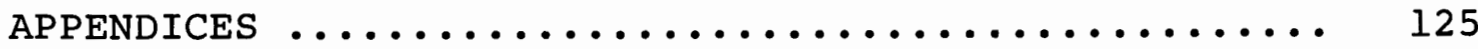

A. EARLY CHILDHOOD EDUCATION IN CALIFORNIA .... 126

B. KINDERGARTENS OPENED IN THREE PORTLAND

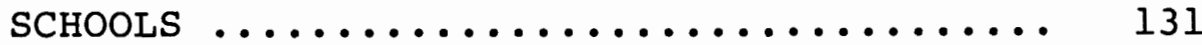

C. KINDERGARTENS: CITATIONS IN LOCAL

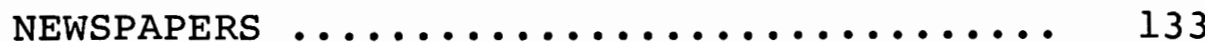

D. THE KAISER CHILD SERVICE CENTERS ......... 136

E. SCHWAB COMMITTEE RECOMMENDATIONS ......... 144 


\section{LIST OF TABLES}

Table

Page

I Professional Background of Early Nursery

School and Kindergarten Leaders .......... 21

II Model Schools Program Funding ........... 81

III Class size ....................... 87 
CHAPTER I

INTRODUCTION

In the introduction to his book Early Childhood Education Rediscovered (1968), Frost states that

The rediscovery of early childhood education has roughly paralleled recent developments arising from massive federal support to the nation's schools. A great deal of this support continues to be directed toward compensatory programming for the disadvantaged child. And it is precisely this focus--the comprehensive reexamination of the teaching-learning process for disadvantaged children--that has resulted in the recognition of certain research and experimental efforts which point to early childhood as a period of critical importance in the development of humans toward intellectual self-discovery. ( $p$. viii)

For those who were just discovering or rediscovering early childhood education the 1960's and 1970's were, in the words of Dickens's novel, "the best of times and the worst of times." Among the disadvantaged children of whom Frost was speaking were a disproportionate number of Black, Hispanic, or other minorities. In the case of the Black child, that child's parents were asserting their rights as American citizens to have their children relieved of the "separate but equal" yoke of educational opportunity and brought into the mainstream of American education.

For the years, roughly between the Brown vs. The Board of Education decision in 1954 and the middle $70^{\prime} \mathrm{s}$, it 
was "the best of times" for researchers and innovators in the field of early childhood education. With a seemingly endless torrent of federal money from President Johnson's Great Society programs with which to fund their research, they were free to examine and redefine long-held ideas about the importance of early experiences on the long-term educational process.

For the school systems, particularly those urban districts with significant Black and economically disadvantaged populations, it was, perhaps, the worst of times. Delivery of services was made difficult by the tensions caused by the mandate to desegregate. Also, research findings had an impact on classroom practice as teachers were required to implement recommendations.

\section{Statement of the Problem}

The decision of the U. S. Supreme Court in the Brown vs. The Board of Education case has caused decades of turmoil for large urban areas. Portland, Oregon, with its increasing black population caused by the influx of Blacks from the South to work in the Kaiser Shipyards during World War II, is no exception. However, by the creation of imaginative school programs and a student voluntary transfer program, Portland has avoided the fragmentation of the community. Though the components of the desegregation/ 
integration efforts of the Portland Public Schools are inextricably intertwined, the emphasis placed upon the development of compensatory education for children in the early years may be examined in light of the discipline known as Early Childhood Education.

\section{Purpose}

The purpose of this thesis is twofold. The first is a brief examination of the development of Early Childhood Education from its beginnings as primarily religious and philanthrophic efforts to aid poverty-ridden, physically disadvantaged preschool children. Its present status as an academic discipline grounded in the child study movement, with emphasis on the cognitively disadvantaged, and encompassing children from birth through eight years of age completes the first purpose.

The second purpose is an examination, in historical perspective, of the use of Early Childhood Education programs as magnet programs for the twin purposes of desegregation and compensatory education by the Portland Public Schools from 1965 to the present.

\section{Questions to be Answered}

1. How have the study and teaching of young children evolved, and what effect did the massive funding by the 
federal and state governments in the 1960's and 1970's have on the redefinition of the discipline known as Early Childhood Education?

2. How has Portland Public School District 1 utilized the discipline known as Early Childhood Education during the period from 1965 to the present to meet the needs of the culturally disadvantaged in the context of desegregation/integration?

\section{$\underline{\text { Procedure }}$}

Collection of Source Materials

A three-pronged survey forms the basis of this thesis. The first was an investigation of general theoretical information about the academic discipline known as Early Childhood Education, gathered primarily from library sources. The second, gathering of specific information from the Portland Public Schools and the City of Portland. The Portland Public Schools information was obtained from the Portland Public Schools Information Office, the Professional Library in the Blanchard Building, and the Records Management office housed in the Child Services Center. The City of Portland information was obtained from the Archives of the City of Portland. Finally, interviews were held with individuals who were involved in the development of various components of the 
Early Education Centers and programs, from the inception of the Model Schools Program to the present. Sources of these interviews may be obtained upon request.

\section{Organization}

The thesis consists of five chapters. Chapter I is the introduction. Chapter II is an overview of the academic discipline now known as Early Childhood Education. Chapter III is a discussion of major funding sources which, from 1965 to the present, enabled the researchers and innovators to examine Early Childhood Education, and which the Portland Public Schools used to implement the innovative Model Schools Program and later the Early Childhood Education Centers' programs. Chapter IV contains a brief chronology of the history of the Portland Public Schools from their inception to 1964. From 1964 to the present the focus of the events described is on the elementary schools in the Model Schools Program and the Early Childhood Education Centers. Chapter V contains conclusions and recommendations.

\section{Limitations of the study}

The following limitations were placed on this study: 1. The study is limited to the academic discipline known as Early Childhood Education. 
2. In reference to the Portland Public Schools this study is limited to Early Childhood Education from the year 1964 to the present.

3. This study is limited to a discussion of compensatory education in the preschool, kindergarten, Model Schools, and Early Childhood Education Centers as well as Head Start and Follow Through. Although Head Start has been sponsored by the Portland Public Schools and is an important part of the compensatory program, it is a separate entity and will not be considered in depth.

\section{Definitions of Terms}

ECE. An abbreviation for Early Childhood Education. Early Childhood Education as an academic discipline. An evolutionary term which first encompassed nonscientific theories about ministrations to children 3 to 5 years of age and more recently has encompassed research-based theories about, and ministrations to, children from birth through age 8 . 
Early Childhood Education relative to the discussion of the Portland Public Schools. Within Portland Public Schools, Early Childhood Education may denote the preschools, Head Start programs, and kindergarten programs. The term also is used to denote programs encompassing Pre- $\mathrm{K}$ through Grades 4 or 5 in the Early Childhood Education Centers. For the purposes of this paper, Early Childhood Education will denote the programs at those sites designated first as the elementary schools of the Model Schools Program and now as Early Childhood Education Centers.

\section{Early Childhood Education Centers (ECEC). Those}

sites originally designated by the Board of Directors of the Portland Public Schools as Model Schools and now Magnet Schools, Grades Pre-K to 4 or 5 for the purposes of exemplary programs for the educationally disadvantaged and for purposes of desegregation/integration.

Follow Through. A program developed and funded, in 1965, by the federal government in an attempt to reinforce and maintain the advantages gained by disadvantaged children in the Head start Program. 
Head Start. A program originally sponsored by the Office of Economic Opportunity and which recruited children from ages 3 to school entry. Portland Public Schools have, from the beginning, been the sponsoring agency for this program, limited to 3 and 4 year olds, because the kindergarten program was, long before Head Start, an integral part of the school system. Head start has been reported on as part of the Model Schools Program although as a separate entity. Head start Programs have never been sited at any of the Early Childhood Education Centers.

Magnet Schools. Those schools in which exemplary programs are designed and developed both for the resident population and to draw students from other residential areas. Though generally thought of as high school programs, the elementary schools in the Model Schools Program were designed for purposes of integration.

Model Schools. The sites designated in the Schwab Report which, during the 1970's, became what is now known as the Early Childhood Education Centers (ECEC). Though there was an "upper division Model School" recommended in the Schwab report, this paper is concerned only with the elementary schools. 
The Schwab Report. The report presented to the Board of Directors on November 16, 1964, by the Committee on Race and Education which proposed the Model Schools Program. 
CHAPTER II

EARLY CHILDHOOD EDUCATION--A BRIEF HISTORY

Themes in the Development of Early Childhood Education

In the seventy-first NSSE Yearbook (1972), Lazerson cites three themes which have dominated early childhood education in the United States:

(1) The expectation that schooling for the young will lead to social reform. As a result, Early Childhood programs have frequently focused on the immigrant and the poor. (2) the importance and uniqueness of childhood; and (3) the impact of Early Childhood Education on the schools. . . Each of these themes-the ethic of social reform, the uniqueness of childhood and the reform of educational practices-has had a variety of manifestations. (pp. 33-34)

Lazerson posits that at various times a particular theme may dominate but that these three themes appear constantly throughout our history and have shaped the development of early childhood education in the United States (p. 35). In this historical overview of the evolution of early childhood education, these themes will, indeed, repeat themselves in the context of the needs of society, whether instigated by the researchers of or practitioners of early childhood education or, as in the recent past, forced upon them. 
Early childhood education is as old as the motherchild relationship for, indeed, mothers were the first early childhood educators. The academic discipline known as Early Childhood Education is, however, relatively young.

\section{Pioneer Theorists and Practitioners}

Braun (1972) notes:

- a distinction was made between socialization (the basic humanization of the child by parents and other close adults) and early education. Although socialization is an essential process, it was clearly an unconscious one until the dawn of anthropological insight in the twentieth century. Early childhood education was also uncontrived until Froebel began to devote his efforts toward a cogent plan and analysis of activities for young children. (p. 46)

Pestalozzi

Froebel would seem to be the first to consider in the field of early childhood education, but a place must be found for Johann Pestalozzi (1746-1827).

Pestalozzi was one of those great teachers whose method is nothing, whose force, power, charm and influence stem not from his theories but from something emanating from his innermost self. (Braun, p. 4)

Pestalozzi's theories formed the basis for many practices in modern education. His theories have had a decided impact on the field of early childhood education (Osborn, 1980). One might say that Pestalozzi represents the beginning point for early childhood education. He had studied law, but discontinued his studies because of poor 
health. He then moved to a farm at Niehof, Switzerland, and when it began to fail he converted it to a school to test some of his theories of education. He opened his school in 1774 for the poor children in the surrounding area. He created a place for them to live and, with the power of love, taught them.

In a letter to Heinrick Gessner (1799), Pestalozzi talked of the school he had opened in Strang, Switzerland:

I wanted to prove by my experiment that if public education is to have any real value it must imitate the methods which make the merit of domestic education; for it is my opinion that if public education does not take into consideration the circumstances of family life, and everything else that bears on a man's general education, it can only lead to an artificial and methodical dwarfing of humanity. (Braun, p. 49)

Pestalozzi believed that the child should learn by doing. He felt that children were much disturbed by too many words being directed toward them which were not adapted to the children's maturational levels or to their frames of reference. Children saw as true that which was connected closely with their own personal observation and experience.

Pestalozzi felt that every person, no matter what his status in life, had a right to an education. He felt that everyone was capable of learning and that all persons should have the right to develop skills which would enable them to fulfill their own potential. He noted that with 
the children he taught he was able to create aspirations and stated in his letter to Gessner that

What encouraged them most was the thought of not always remaining poor, but of someday taking their place again amongst their fellows with knowledge and talents that should make them useful, and win them the esteem of other men. (Braun, p. 53)

Froebel

Friedrich Froebel (1782-1852), known as the father of the kindergarten, studied with Pestalozzi, then the best-known teacher in Europe. Froebel felt that there should be more structure to the learning process. Toward this end he developed a set of occupational methods and materials known as Gifts and Occupations. The gifts were to be used in a precise order. They included balls, cubes, blocks, and cylinders. The occupations included the use of these gifts and other activities. The occupations were also precisely ordered. After teacher-dominated instruction the child manipulated the gifts in order to discover the intrinsic logic in them in relation to the world of nature.

Froebel, as opposed to Pestalozzi, was an urban man. He saw and could understand what effect factory life in crowded cities and what the absence of parents from the home could do to children. He understood that with industrialization the world was radically changing. Froebel respected the individuality of each child, and yet 
understood the demands which society would make upon the child, and felt the obligation to impart to the child the knowledge and values which would allow the child to be a member of the larger society (Braun, 1972).

Montessori

Maria Montessori (1870-1952), the first Italian woman to receive a medical degree, in 1907 established the Casa dei Bambini (Children's House) in a tenement district in Rome. She drew ideas from Pestalozzi, Froebel, and Freud. Montessori was working with poverty-ridden children. She felt that education began at birth and that the first few years of a child's life were most important. She also felt that the home and the school must work together for the good of the child. She believed that the role of the teacher was to be an active observer of the child's readiness for new tasks, introduce the tasks, and then help the child toward independence in mastering them. Evans (1971) states:

The Montessori method is a provocative combination of philosophy, psychological concepts, and pedagogical techniques. It is fueled in principle, by love for the child and respect for his natural capacities. It is the child in whom Montessori placed her hopes for a world based upon fundamental values such as cooperation, self-control, order, responsibility, patience, and the common good.

Montessori visited the United States in 1912 to give several lectures, and an American Montessori Association, headed by Mrs. Alexander Graham Bell was founded. The 
Montessori Method fell into disrepute in the united states until, in the late 1950's, interest in it was revived. There are now more than 1,000 schools in the United States which claim to follow the Montessori Method.

The MacMillan Sisters--The Rise of the Nursery School

The nursery schools movement essentially began with the MacMillan sisters, Margaret and Rachel. Originally socialist political crusaders, they were affected by the plight of the young children of London who lived in poverty. Convinced that children's health problems would be too far advanced by the time they were of school age, they formed the open Air Nursery. In 1893 they opened a nursery school in a structure akin to a lean-to. Three years later Rachel died but Margaret went on with her work of training teachers and promoting nursery school until her own death in 1931 (Braun, 1972).

The open air centers served children from ages one through six. In light of the Head start Program of the 1960's and '70's, the MacMillan's concept of the nursery school, including provision for medical and dental care, cognitive stimulation, and work with parents, is most interesting.

Among the notable early American nursery schools were the Merrill Palmer Institute in Detroit, Michigan, begun in 
1922 by a home economist, Edna Noble White. Also in 1922, Abigail Eliot, a social worker, began the Ruggles street Nursery School in Boston, Massachusetts.

\section{Early American Kindergartens}

Kindergarten in the United States developed initially on the Froebelian principles. Mrs. Carl Schurz, who is credited with opening the first kindergarten in the United states, in her home, in 1855 had studied in Germany under Froebel. The kindergarten was conducted in German for her own and relatives' children.

Elizabeth Peabody, of the Boston Peabodys, opened the first English-speaking kindergarten in 1860, based on the Froebelian kindergarten of Mrs. Schurz (Osborn, 1980).

Religions and Philanthrophic Influences

Between the 1880's and 1915 industrialization and immigration were growing rapidly in the United States and creating difficult urban situations. Something needed to be done and citizen campaigns were instituted to combat political corruption and the rising costs of government in the large cities. On the labor front, reforms were being sought in the form of improved working conditions and legislation against exploitation of children. Food and 
drug legislation was passed. Social scientists embarked upon research which they felt would lead to social justice. The kindergarten, early on, was based upon philanthropy on a large scale. In the late 1900's kindergartens began springing up, sponsored by settlement houses, the Women's Christian Temperance Union, and other charitable organizations.

The Free Kindergarten Association was organized in Cincinnati in 1879 to help the little children in the poorer districts of the city.

Well-born, intelligent young women prepared themselves in normal schools supported by religious and philanthropic organizations and went forth in most of the urban slums of the large cities all over the country to make life better for the children of poverty. Fisher

\section{(1908) notes:}

Centering among, and concerning itself with, the children of the poor, and having for its aim the elevation of the home, it was natural that the kindergarten as a philanthropic movement should win great and early favor. The mere fact that the children of the slums were kept off the streets, and that they were made clean and happy by kind and loving young women; that the child thus being cared for enabled the mother to go about her work in or outside the home--all this appealed to the heart of America, and America gave freely to make these kindergartens possible. (pp. 19-20)

An interesting precursor of the future was in the programs of these kindergartens. It was immediately felt 
that there was need for doctors, nurses, social workers, and visiting teachers to go into the homes to help the parents. So, essentially, the first kindergartens were for the disadvantaged.

Transfer to Public Schools

The kindergartens were finally too expensive for religious and philanthropic organizations to support, and the supporting groups requested that the public schools assume the responsibility for the kindergartens. This was difficult for the philanthropic and religious supporters to accept since the public schools were considered lacking in interest in the whole family.

Susan Blow, a prominent educator and leading proponent of the Froebelian kindergarten in America, was the director of the first public school kindergarten in the United States. This was in St. Louis, Missouri. In this position she trained kindergarten teachers. While working in the public school kindergarten, Blow encountered a problem which most future kindergarten teachers would encounter. Her kindergarten, after a change in school policy, was placed under the jurisdiction of elementary grade supervisors. Fearing that the kindergarten would suffer from the rigidity of the elementary school she and her supporters resigned their positions. 
With the burgeoning of kindergartens in the first quarter of the twentieth century due to the rapidly increasing urban populations, the kindergarten became more and more part of the public school system (Osborn, 1980, p. 114). Weber (1969) notes that "as kindergartens became a part of public school systems, teachers could no longer maintain the self-worshipping aloofness so characteristic of earlier days; they were forced to promote continuity between the child's kindergarten experience and the first grade programs" (Osborn, 1980, p. 114).

\section{Training of Teachers}

Philosophical Differences of Opinion

The next group of kindergarten teachers were trained in the universities. With this, two interesting problems developed. One was the schism between the philosophies of the conservatives (Froebelians) and the progressives (those influenced by the psychologists and philosophy). For approximately twenty years a strong but friendly philosophical battle ensued. Finally, with time, the advocates of both philosophies came to study any and all subjects which could help solve their common problems and enable them to study the child in a more scientific manner (Weber, 1969). 
The Multidisciplinary Aspect of Early Childhood Education

The second problem dealt with the term "early

childhood educator." The coalition of kindergarten

teachers in private kindergartens who had to have no public school certification and the various disciplines in the nursery schools, nursing, home economics, social work, etc., caused a real schism in the early childhood education movement since the kindergarten and nursery school teachers called themselves the early childhood educators. However, those who were in the universities studying KindergartenPrimary Education also considered themselves early childhood educators. There was very little communication, even antipathy, between the two groups. An examination of Table 1 (p. 21) clearly shows the extent of the multiple disciplines of the early nursery school. It may be noted that the kindergarten leaders were largely from the field of Education (Osborn, 1980, p. 122).

By the 1920's the programs known as KindergartenPrimary in the Departments of Education in universities had gradually evolved into an educational unit.

Impact on the Public Schools

Early on in this kindergarten-primary alliance the kindergarten people attempted to extend the kindergarten philosophies into the first grade classes, and did, to some 
TABLE 1

PROFESSIONAL BACKGROUND OF EARLY NURSERY SCHOOL AND KINDERGARTEN LEADERS

Kindergarten

Johann Pestalozzi (Educ.)

Friedrich Froebel (Educ.)

Maria Schurz (Educ.)

William T. Harris (Educ.)

Elizabeth Peabody (Educ.)

Susan Blow (Educ.)

G. Stanley Hall (Psych.)

John Dewey (Educ.)

Patty Smith Hill (Educ.)
Nursery School

Rachel \& Margaret McMillan (Nursing)

Abigail Eliot (Social Worker)

Maria Montessori (Medicine)

Edna Noble White (Home Economics)

Bird Baldwin (Psychology)

Harriet Johnson (Nursing)

Arnold Gesell (Child Devel.)

Patty Smith Hill (Educ.)

degree, with the relaxation of the rigid atmosphere in which the 3R's were paramount. Though they were missionaries in their zeal, the kindergarten practitioners fell far short of their goal, so delightfully expressed in 1896, by Colonel Francis W. Parker (1896):

In the kindergarten is the seedcorn, and germination of the New Education, and the New Life. The seed has been planted, the buds, and flowers are turned toward the sun: Let not the chilling frost of traditional teaching blight, and wither them. One, and all of the true principles should be applied (simply changing the application to adapt it to different stages of growth) through all education, up to the gates of heaven. (p. 157) 
The public school felt, however, that curriculum changes should not be all in one direction, and the traditional schism in philosophies between kindergarten and the primary schools remained. In kindergarten there was a spirit of cooperation, play activities, and comradeship. In the primary school there were strictly individual intellectual activities. Those who dealt with the kindergarten and primary grades felt that with the two philosophies there was a large discontinuity in the child's education experience.

Patty Smith Hill (1907) felt that kindergarten and primary teachers had to know each other's problems and methods. She stated:

Until there exists mutual insight and understanding we can neither expect intelligent cooperation between kindergarten and primary teachers, nor a bridging of the gulf between the kindergarten, and primary school. (Weber, 1969, p. 117)

In 1906 there were 137 private kindergarten training schools and 54 kindergartens-primary departments in normal schools or colleges. In 1920, the Proceedings of the International Kindergarten Union (IKU) at its 27 th annual meeting announced that there were only 31 private kindergarten training schools and 109 kindergarten-primary departments were part of normal schools or universities. With the training residing in normal schools and universities, the width and length of training expanded. 
The proper young women who had gone into the slums with great philanthropic zeal, but little actual education were not adequate. Some schools were elevating course work to the graduate level. By 1930, $80 \%$ of teacher-training institutions were training kindergarten-primary teachers. This training was centered in two departments, Home Economics, which were most concerned with the nurturing aspect of childhood, and Departments of Education, which were concerned with the educational. There was development of new curricula to meet the needs of both areas of interest.

Two centers were leaders in providing advanced study in kindergarten-primary education. These were Columbia Teachers College under the directorship of Patty Smith Hill and the University of Chicago under the administration of Alice Temple. These two administrators had their early training under teachers who were breaking with Froebelian tradition, and both were receptive to the new ideas of the leaders of the educational scene.

Association of Early Childhood Educators Formed

Patty Smith Hill in 1925 called a meeting at Columbia Teachers College and formed The National Association of Nursery Education, NANE as it was called. This group was the forerunner of The National Association for the Education of Young Children, NAEYC (Osborn, 1980). 
The depression of the 1930's in the United States brought about a mushrooming of nursery schools. There were thousands of out-of-work teachers and they were put to work in nursery schools by the federal government's Work Project Association. Nursery school practitioners were most unhappy. The National Association for Nursery Education formed an advisory council with the Association for Childhood Education and the National Council on Parent Education to develop guides, etc., to be used in the nursery schools.

\section{The Child Study Movement}

Early childhood education gained more stature and acceptance as it became concerned with the new science of child study.

$1920^{\prime} s-1950^{\prime} s$

The 1920's were a good time for this science to have its beginning--namely, the business climate was good and there were funds from foundations for research. Also, it was a time in which there was much faith that science could solve social problems. Also, rapid strides were being made in medicine, biology, psychology, chemistry, and nutrition. Since the White House Conference on Children had alerted the public to the poor physical and educational conditions 
of the World War I army recruits, there was renewed interest in the welfare of children. This quickly led to processes for improving infant and child development-well baby clinics, school health programs, child guidance clinics, etc.

Although, early on, interest in early child development research resided largely in the nursery school pioneers, among them Patty Hill Smith, Edna Noble White, and a nurse named Harriet Johnson who would found what would later be the Bank street School, a catalyst for institutionalizing the study of children was Lawrence $K$. Frank.

Frank had been trained as an economist but "people" were his major interest and during his college days at Columbia he had worked as a volunteer and paid worker for the Bureau of Social Research studying the Lower West Side of New York City--an area of abject poverty. In approximately 1933 Frank wrote, in an unpublished paper titled "Child Welfare Research" (Senn, 1975):

If a comprehensive program of child development research were organized in connection with university laboratory schools, both elementary and secondary, not only would the child welfare research [i.e., child development research] be advanced but the impending reorganization of education would be greatly helped. It is evident that the program of the schools must be reoriented in the light of the needs and interests of growing children, and the variety of health and other welfare activities in the 
schools must be directed by active program of experimentation and research if the schools are to serve the needs of children and of the changing social conditions. (p. 14)

Through funds, largely from various foundations, Frank was able to carry his idea of university study of child development forward in many areas. Often in the universities there was conflict over which department of the university would have jurisdiction and in some notable instances, home economics, where he felt the programs should reside, were most unhappy with the idea.

Though he never did any actual research himself, Frank has been considered the catalyst which moved the child study movement forward. Frank was the ultimate "grant writer."

One notable researcher was Bird Baldwin. He set up a child study laboratory at the Iowa Child Welfare Research Station at the University of Iowa. In $1921 \mathrm{Dr}$. Bird Baldwin began a six room "lab" so that he could observe the same group of young children daily over a period of several years (Braun, p. 150). Baldwin (1922) stated:

The children are occupied with a simple, flexible schedule of singing, games, stories, rhythm exercises and simple occupational projects. A graduate assistant keeps a detailed log book of observations made on the children and notes interesting reactions and the conditions under which new abilities develop. (p. 147) 
Gesell

Arnold Gesell (1880-1961) was one of the prime movers in the early childhood education movement. He had studied with G. Stanley Hall. Later he established the Clinic of Child Development at Yale University. Gesell's largest contribution toward moving early childhood education into the scientific age was recording behavior of children. Gesell and his associates collected normative data on young children and from this developed his theory of maturation. He did not wish his "ages and stages" concept to be interpreted rigidly as he felt that each child had his own individual "timeclock" which determined his readiness for any learning. Gesell felt that the early years were the most important as it was the first in sequence and all was built on those years (Braun, 1972). In 1970, nearly 50 years later, Elkind (1970) echoed Gesell's thoughts.

The preschool period is important, even critical, but not because growth is most rapid at that time, it is important for a simple reason, namely, mental growth is cumulative and depends upon what has gone before. (p. 37)

\section{Cognitive Psychologists}

Move Toward Emphasis on Cognitive Development

Braun (1972) notes that in the 1950's major shifts away from the idea of a fixed intelligence came from the work 
of the cognitive psychologists. They argued for the responsiveness of intelligence to experience.

NSSE (1972) discussed the work of three men who have been widely associated with contemporary child study:

The work of J. McVicker Hunt, which gave a new appraisal of the effect of the environment on the developing organism, that of Jerome S. Bruner, which suggested new instructional approaches, and that of Benjamin S. Bloom--all pointed in one direction. If the vicious cycle of apathy, lack of aspiration and waste of human potential perpetuated by poverty was to be broken, then substantial energies and efforts must be directed toward the children of poverty at a very early age. (p. 2)

Familiarity with the interactionist viewpoint of Jean Piaget was an important influence for this change.

Piaget

An important contemporary figure, perhaps pivotal, in early childhood education is Jean Piaget (1896-1980). Piaget's early interests were in the biological sciences. He had published zoological studies before the age of 16 . Piaget became interested in the study of intelligence when studying under Alfred Binet in Paris. This led him to a fascination with the child's thought processes and using observations of his own children he developed a theory of cognitive development.

Piaget made three main points about the qualitative stages of intellectual growth: they form an invariant 
sequence, they are hierarchically related, and they show integration within each step (Osborn, 1980, p. 126).

Though Piaget considered cognitive growth to be a continuous process he specified four main periods of intellectual growth. The four periods are:

1. The sensory motor stage (0-2 years)

2. The pre-operational stage (2-7 years)

3. The concrete operational stage (8-11 years)

4. The stage of operations (11\&up)

Another facet of Piaget's thought (1966) about intellectual growth was that it was a developmental process involving two interactive functions between the individual and his environment: (a) inward integration or organization, called "assimilation," and (b) outward adaptive coping, call "accommodation." Further development depends on these external and internal factors "equilibrating" each other through the regulation and self-corrections of the person. His theories have had great influence, especially since the movement in the early 1960's toward cognitive stimulation in young children (Osborn, 1980).

Hunt

J. McVicker Hunt, psychologist and author of the landmark Intelligence and Experience (1961), has been a leader in the movement that has theorized that intelligence 
is not fixed at birth but receptive to environment. His studies have demonstrated the importance of early perceptual and cognitive experiences. According to Hunt, interference in an infant's locomotor and manipulative development may result in negative effects that can be long-lasting. Hunt's work was influential in a resurgence of interest in Piaget and Montessori.

Bloom

In his book Stability and Change in Human Characteristics (1964), Benjamin Bloom felt that genetic influences could not be the basis for determining a fixed intelligence because intellectual development was a part of the environment in which the individual lived. His review of studies of development of intelligence led to the conclusion that $50 \%$ of intellectual development took place between conception and age 4, $30 \%$ between ages 4 and 8 , and about $20 \%$ between ages 8 and 18 .

Bloom (1964) felt that differences in general intelligence are likely to be related to:

1. Stimulation provided in the environment for verbal development;

2. Extent to which affection and reward are related to verbal reasoning accomplishments; and 
3. Encouragement of active intervention with problems, exploration of the environment, and the learning of new skills. (p. 190)

\section{Bruner}

Jerome Bruner is a social psychologist who teaches at Harvard University and is studying children from 4 months to 3 years of age. His research centers on the cognitive process and motor control, with emphasis on teaching methods. Bruner has gained fame for, among other accomplishments, his oft quoted hypothesis that "any subject can be taught effectively, in some intellectually honest form, to any child at any stage of development (Fallon, 1973, p. 211).

\section{The Rise of Compensatory Education}

By the late 1950's and early '60's, with the push of the War on Poverty as well as the civil rights movement, there was an avalanche of research begun to study the problem of the relationship of early experience, poverty, and compensatory education. Martin Deutsh's compensatory education project with the prekindergarten children of Harlem was one of the early projects. He and his group from The Institute for Developmental Studies at New York 
University attempted to develop a curriculum with special emphasis on making up cognitive skill deficits.

\section{Defining and Redefining Early Childhood Education}

Only two journal articles will be cited in this discussion, but they were chosen because they seem most graphically to present an inherent problem in the academic field known as Early Childhood Education. This is the plethora of points of view regarding what the term "early childhood education" encompasses. The fact that both of these articles came from Young Children, the journal of the National Association for the Education of Young Children (NAEYC) and their time sequence (within 7 months of one another) contribute added significance toward pointing up several problems in attempting to form one specific set of parameters and, finally, one definition for early childhood education.

The California Early Childhood Education Credential

The May 1970 issue of Young Children contained an article by Marjorie S. Morris entitled "The California Credential Story: A New Specialization for Teachers of Young Children" in which the struggle for credentialing of early childhood education teachers was discussed, the culmination being Governor Ronald Reagan of California 
signing into law, on September 4, 1969, Senate Bill 982, which established a standard Teaching Credential with specialization in Early Childhood Teaching. Early childhood education was defined as preschool through grade 3 (Morris, 1970, p. 279). This bill had not been easy to accomplish, in fact had been a 20-year uphill struggle. However, in 1969 conditions were excellent for its passage. There was current public recognition of the importance of early education. In 1965, the year that the ESEA was passed, Lyndon Johnson had mentioned the importance of early learning experiences in his State of the Union Message to Congress. He stressed that there was evidence that children of parents who were poor and uneducated became discouraged and tended to fall behind as students and become school dropouts. President Johnson proposed that we begin to educate them before they entered kindergarten in order to give them a "Head Start" in the academic race. By these remarks President Johnson placed the field of early childhood education directly into the center of the political arena.

Those engaged in working with young children were heartened. Until then "few public officials were even slightly aware of or interested in learning about the implications of research findings or the results of early 
childhood education for poverty stricken families" (Morris, 1970, p. 272). However, when massive federal funding became available it was remarkable how many state legislators suddenly understood the importance of and implications of early childhood education.

Until 1965 there had been a Kindergarten-Primary Credential in the state of California, but it was offered by only five institutions and it rarely offered adequate preparation of prekindergarten or nursery school teaching. The Kindergarten-Primary Credential was then eliminated, giving those who held Kindergarten-Primary credentials lead time. By 1974 applicants who held Kindergarten-Primary credentials and who had completed five years of college were eligible for a new Early Childhood Education Credential; those who had not completed the fifth year of college were to be eligible on the basis of postponement of requirements. Teacher education institutions would determine whether candidates were qualified to receive credentials beginning in 1974 (Morris, 1970, p. 279). Though understandable from the point of view of quality early childhood education, this would seem to have been an unthinking and uncaring attitude on the part of the state Department of Education because those who had in the past chosen to take the Kindergarten-Primary Credential by being dedicated and determined to specialize in educating young 
children, the only option open in Departments of Education in institutions of higher learning, took that training knowing their job opportunities were limited to teaching grades $\mathrm{k}-3$ rather than taking an elementary certificate enabling them to teach grades $\mathrm{k}-7$ or 9. Morris (1970) states :

Though California got its ECE certificate in 1969, in 1967 and 1968 conversations with friends and advisors who were most familiar with state politics and procedures had led to suggestions that early childhood educators might hire a professional lobbyist, which would "guarantee" passage of the bills. One might expect that 20 or 30 years of failure and discouragement would have tarnished a lot of idealism. But either their ideals or their "naivete" led the teachers to reject the idea, even without finding out how much it might cost. (Morris, 1970, p. 278)

In November of 1969, the Committee on Consultation and Teacher Education of the California Association for the Education of Young Children invited representatives of colleges to an informal meeting to discuss plans for developing programs which would lead to the new credentialling. It was stressed in the discussions the need for interdepartmental and interdisciplinary academic majors. Among these were education, home economics, sociology, psychology, medicine, and anthropology. Also stressed was a great deal of laboratory work with children. 


\section{A Theorist's Viewpoint}

In the December 1970 issue of Young Children an articled entitled "Early Childhood Education as a Discipline" by Dr. Lilian Katz, then an Associate Professor of Education and director of the ERIC Clearinghouse on Early Childhood Education housed at the University of Illinois, noted that the gathering, organizing, and analyzing of information about early childhood education had raised some interesting questions about what was encompassed by the term "early childhood education." Dr. Katz, in the introduction to the article, specifies a tentative, generally held definition of the term as follows :

It is common to speak of early education as an interdisciplinary field encompassing the interests of specialists in developmental psychology, pediatrics, social work, anthropology, elementary education, and other fields. (p. 82)

After stating that young children had been the subject of developmental inquiry for more than half a century, she indicated that their education had not. She suggested that "a distinct disciplinary approach has been neglected in favor of problem-oriented investigations designed to discover the most powerful way to offset the ill effects of poverty" (1970, p. 82) 
For the purposes of her rather extensive article, Dr. Katz states the following operational definition of early childhood education:

"Group settings which are deliberately intended to effect developmental changes in children in range from birth up to the age of entering the first grade [emphasis mine]" (1970, p. 83). Dr. Katz then goes on with the definition:

Education rather than child development or child rearing becomes the point of entry into the field, thus giving early childhood education disciplinary status in its own right. From this definition, the parameters of the field can be derived, and can then provide basis for the development of the branch of knowledge called Early Childhood Education. (1970, p. 83)

Dr. Katz comments on her definitions in relation to the cut-off point for the age of entrance into school, creating an undesirable division between preschool and primary education and suggests that that is a division that the profession has been striving to reduce.

The two articles cited above seem to point out clearly a basic problem within the discipline which calls itself Early Childhood Education. Having grown, unlike most academic disciplines, out of a multitude of separate disciplines and having the three major groups of practitioners, nursery schools, kindergarten, and primary public education, one clear-cut, definitional, theoretical or 
pragmatic base which the early childhood education discipline could rally behind seems not to emerge. This rallying point would seem to be a necessity in order to gain political power, solidify the priority given, based upon sound scientific data, to the compensatory education of the young child in the 1960's and '70's, and to make this priority a springboard for future political action and acknowledgement by the academic community and the population at large that the early formative years of a child's life are the most important that he would ever have. Attention by society at large during these years would be not only of benefit to the child but to the society as a whole.

\section{Two Innovative Programs in the Public Schools}

The two programs chosen as illustrations for this section have two specific thrusts. The first is a discussion of an early childhood program model devised for an entire state. The second is a program model designed for an individual school.

The California Plan

Desiring to revitalize and restructure early childhood education in California, Wilson Riles, Superintendent of Public Instruction, appointed early in the 
1970's a Task Force on Early Childhood Education, giving them the responsibility for developing a comprehensive integrated plan for children to the age of 8 years old in the California Public School System. On November 26, 1971, the task force presented Riles a report on its efforts. The task force stated the following philosophical basis for its work: "The past decade has produced a new body of educational, psychological, and medical research documenting the crucial importance of the first eight years of life" (Benesch, 1978, p. 53).

The task force listed six goals for the program, including the long range commitment of funding; the commitment of equal opportunity to all children; the idea that school should be a happy place and one of continuous progress; the importance of parents in the educational process; local school district autonomy and creativity; and, finally, the idea of a broad-based educational program for the young, including the four year olds. (See Appendix A for full text.)

The task force went on to say:

The plan for Early Childhood Education has as its goals the restructuring of primary education for California's public school children. The program for young learners from four through eight years of age does not suggest "more of the same" or "pushing kindergarten downward." It provides for a system of public education that offers "access to success" to all children. (Benesch, 1978, p. 53) 
Dr. Riles also described the band-aid techniques used by California for dealing with the problem. Many of these will sound familiar to those engaged in ECE.

Many different programs, both public and private, have been developed in California in an attempt to provide desirable educational experiences for children before they come to school. The following information reveals, however, that these programs are not offered to all children equally and that they are operated under such a wide variety of auspices that costly fragmentation of effort is inevitable:

1. The Division of Compensatory Education in the State Department of Education coordinates the state preschool program; ESEA, Title I, preschools; migrant preschools; and children's centers. Other preschool programs, such as Head Start, parent participation nursery schools, and parent cooperatives, are not part of this coordination effort.

2. Compensatory programs serve only 50 percent of the approximately 60,000 economically disadvantaged four-year-olds in this state. These programs serve only 29 percent of the total population of four-year-olds.

3. At present, school is not mandatory until age six in California. Kindergarten is optional in this state, and approximately 15 percent of our five-year-olds do not attend kindergarten.

4. Many positive but uncoordinated attempts have been made to meet the educational needs of five- through eight-year-olds. Examples of these include ungraded primary schools, the use of teacher assistants, innovative instructional materials, and individualized teaching techniques. Federal and state funds have been provided for these supplementary school programs affecting five- through eight-year- old children who are in special categories. 
5. ESEA, Title I, and follow-through programs serve roughly 40 percent of the pupils who are eligible on the basis of economic disadvantage. Miller-Unruh programs serve approximately 50 percent of these pupils. Enrollment in other programs offered under migrant education or ESEA, Titles III, VI, or VII, is relatively light.

6. Approximately 76,000 four-through eight-yearold children are in programs for the exceptional. This includes the deaf, hard of hearing, blind, partially seeing, orthopedically handicapped, aphasic, mentally gifted, and educationally handicapped; children in developmental centers for handicapped minors; and children in speech therapy. However, the State Department of Education estimates that there are more than 90,000 additional exceptional children in this age group who should be receiving special services. These children would receive such services as a result of the new primary school plan if it were to be fully implemented. (Benesch, 1978, p. 54)

Using the task force report, Dr. Riles developed a MASTER PLAN for restructuring early childhood education from kindergarten through third grade in California. The Master Plan was divided into two parts; the first dealt with the rationale of the plan.

In this section Dr. Riles cited:

1. The Importance of Early Childhood Education

Dr. Riles expressed hope, based upon research showing the critical nature of early learning that early intervention would help alleviate the problem of failure of children to succeed in school. 
2. The Problems Involved

Dr. Riles, noting the costs of failure of children who by the third grade have not mastered the basic skills of reading and arithmetic, cited the following:

1. In nearly one-third of the elementary schools, $75 \%$ of the boys and girls achieve less than one month's growth in reading for one month's instruction.

2. In one-tenth of the schools, more than one-half of the children are severely retarded in reading by the third grade.

3. California's state average ranks markedly below national norms when arithmetic skills are measured at the sixth grade level.

In addition, it has been determined that one out of every six high school students drop out of school before graduation (Benesch, 1978, p. 59).

3. Recommendations for Coordinating and Strengthening $\underline{E C E}$

Citing analysis of prior program weaknesses Dr. Riles cited the following components as recommendations.

1. Needs assessment for program purposes and objectives be geared to requirements of learners.

2. Enrollment of children at age 4, to be made optimal.

3. Citing the federal Follow Through Program it was recommended that a similar plan follow children as they progress through school.

4. Coordination of all ECE programs into one concentrated effort directed toward clear-cut goals. 
5. Individual diagnostic instruction.

6. Parent involvement.

4. Development and Implementation of the School District Plan

Each school district would develop its plan for ECE which would be consistent with state guidelines and must meet the unique needs of the community. would be:

The components of each school district's plan

a. School by school assessment in relation to resources and needs with emphasis upon the basic skills of reading and language development and mathematics

b. Staff development

c. Parent-community involvement

d. Auxiliary services

e. Evaluation of the program

f. Coordination and continuity of resources

g. How program will be initiated

5. The Role of the State Dept. of Education

To provide leadership and services to school districts to insure the success of the ECE program.

1. Helping identify the goals and objectives of education.

2. Organize internally to achieve statewide goals.

3. Provide leadership and technical assistance. 
4. Training and retraining of school administrators who can manage the total learningteaching environment.

5. Coordinating statewide efforts.

6. Sponsoring changes in legislation and administrative regulations.

7. Developing guidelines and application and evaluation procedure.

8. Conducting statewide evaluation.

9. Serving as an information center for school districts.

10. Expanding provisions for day care.

6. The Function of Other Agencies

1. Teacher Preparation Institutions

a. Course content to include more emphasis on how human beings develop and learn.

b. Training in diagnosis problems in reading, language, and mathematics.

c. Study in related areas, such as adult education, parent and family life, sociology of the community and other cultures.

d. Inservice.

2. The Commission for Teacher Preparation and Licensing

a. Will be issuing two new credentials in addition to credentials already authorized. One will be Multiple subject Instruction and the other Specialists Instruction for Early Childhood Education credential.

3. Community Colleges

a. Transferrability to four-year colleges and universities of ECE credits. 
The second part of the MASTER PLAN considered the funding of the plan; the Parent Participation and Extended Day Care components; administration of the ECE program by the State Department of Education, and other legislative provisions.

Some attention should be given to the Parent Participation and Day Care components.

Parent Participation in the Program
a. Parent Education
b. Parent Counseling
c. Parent Advisory Committees
d. Formalized Parent Education

These formalized parent education classes by district to be available not only to parents of four year olds but to $\mathrm{K}-3$ also. Those unable to pay would be eligible for Title IV-A of the Social Security Act.

Extended Day Care and the Early Childhood Program

a. Will use already established children centers, day care centers, and other day care facilities to provide primary programs for children ages $4-8$.

On November 27, 1972, California Governor Ronald Reagan signed Dr. Riles's proposal for redesigning and revitalizing ECE into law. However, there were some significant amendments to the proposal as originally drafted. They were: 
1. Four-year-olds have been deferred for two years. The plan now includes only $\mathrm{K}-3$ children.

2. For the first year, 12 per cent of the primary children will be included. The figure was originally set at 15 per cent.

3. The cost for the first year is $\$ 25,000,000$. The original figure was $\$ 51,000,000$.

4. For the second year, the total figure is $\$ 40,000,000$. It was originally $\$ 121,000,000$.

5. Although the funding was originally intended to be on a five year phase-in basis, the amended bill now requires another appropriation bill after the second year. (Benesch, 1978 , p. 58)

Though research stresses the importance of early learning, apparently the budget of the state of California was not too certain.

\section{Kramer School}

The Kramer Project (Braun, 1972) began in 1969 through a "Special Facilities" grants program of the Children's Bureau. The project was developed in conjunction with the Department of Elementary Education of the University of Arkansas and the Little Rock, Arkansas, Public Schools. It was directed by Dr. Bettye Caldwell and took place in the Frederick W. Kramer School (p. 373).

Philosophically, Dr. Caldwell felt that, based upon prior experience with a research-based day care and education program which offered services to infants and 
young children and their families but which lost contact with them at school age, early childhood education would never have a significant impact upon the children of America until it became part of public education. Also, she felt that the schism between early childhood education and elementary education had to be bridged. So she designed a program, the Kramer Project, which provided age appropriate developmental guidance from early infancy to the end of the childhood years. Kramer School, in Little Rock, Arkansas, the site of the project, was located in a section of town which had a large number of low income parents and a racially integrated population.

In a discussion of the components of the program Dr. Caldwell suggests that each of the components in isolation would be a worthwhile educational endeavor but "which put together in the right combination represent something more--an exciting program model worthy of consideration for adoption in other communities concerned with designing a school environment capable of meeting the needs of young children and their families" (Braun, 1972, p. 373). Following are the components: 
1. A comprehensive early childhood program beginning in infancy

Citing the experimental data gained in the '60's on early intervention, Dr. Caldwell expressed happiness in the fact that "during this decade [the 1970's] early childhood education, always either a step-child or a petitioner for educational legitimacy has gained a new lease on life" (Braun, 1972, p. 374). So, Dr. Caldwell planned an infant program to be integrated into the school program right in the same building in which older brothers and sisters were going to school. This program did not involve simply backing down from first grade but rather moving forward from birth with activities designed to provide ageappropriate developmental supports (p. 374).

\section{A dynamic elementary program offering continuity of developmental support}

Upon completion of the early childhood program the child simply moved on up the education ladder. By design, the kindergarten and first grade rooms were adjacent to each other with some children moving between them for the better part of the day. For example, readers in the first grade who felt more need for readiness spent the main work period in the kindergarten and the kindergarteners who were readers spent that time in the first grade room. 
The program, responding to criticism of public education, lay on a point midway on the continuum between a highly structured program and a completely open program. Caldwell states that developing the early childhood education program was far easier than influencing the elementary program. "It is not easy to change a school, as thousands of people who have tried in the past will testify" (Braun, 1972, p. 378). However, some gains were made. The school became nongraded with a great deal of interaction between different aged children. The terms preschool and school children were discarded for preparatory and elementary division.

3. Day care for all children who need this service

Caldwell's philosophy includes the idea that day care can most logically and economically be expanded by establishing a liaison with public education, so at Kramer the school opened at 6:30 A.M. and closed at 5 P.M. An added benefit for the elementary teachers was having qualified personnel to watch the students during play periods before and after school.

4. A broad research program in child development and education

The University of Arkansas was interested in the opportunity to influence public education and to 
participate in research to develop a model school. The project's major concern was the influence of the total environment on the development of the child. The following specific research topics were addressed:

home factors influencing early learning, interrelations among different types of learning (cognitive, social, emotional), the predictability of early performance, the development of internalized behavioral controls, naturalistic studies of classroom and home behavior, the relative effectiveness of different types of enrichment models, the development of a human relations program for the elementary school, the utility of prereading training designed to foster the acquisition of conservation, the development of a language laboratory for two- and three-year-olds, consonance and dissonance between values for young children espoused by parents and advocated by the school. (Braun, 1972, p. 381)

\section{A comprehensive array of supportive family service}

The Kramer school's broad spectrum of family life styles; separate areas of black and white housing; stable and long term residences and transient housing; an area in which approximately $75 \%$ of the mothers worked out of the home demanded support staff. There were two social workers, one school psychologist, and one aide. Their broad duties were any or all which would bridge the gap between school and home, including such mundane activities as arranging for food or clothing for a family or arranging a rummage sale, to leading the "parent sounding board" known as the Community Action Council (Braun, 1972, p. 382). 
6. A training program for staff and students

This included preservice and inservice. It is in

this area where the greatest convergence and knowledge of each other that the preparatory and elementary staff benefitted.

Comparing the preparatory staff with the elementary grade staff, Caldwell indicates the feeling that those of the preparatory staff seemed to have a feeling, as it seemed to come so easily to them in early childhood education, that having been the stepchildren of formal education so long they couldn't really know anything important. Conversely, the opposite was true of the elementary teachers; they had credentials which proved that they had the skills necessary to teach.

Also, Caldwell was aware that the separate viewpoint about children and of the learning environment by the preparatory and elementary staffs could impede the project. She felt it most important to attempt to bridge the gap between philosophies in order to create continuity and flow in the program.

Continuing her discussion of the faculty and of faculty meetings and the freeing up of teachers' time for them, Dr. Caldwell noted that in the faculty meeting there was leisure to discuss total program problems and controversial subjects and to be critical of some aspects of the 
program. Caldwell commented that she had noted that the elementary teachers had criticized things done in the preparatory division but that she could not recall any instances of criticism going in the other direction. Dr. Caldwell attributed this to a possible feeling of inferiority on the part of the preparatory teachers.

The most important element of the Kramer School Project, in Caldwell's opinion, is the remaining major component of training endeavors and that is with the future teachers enrolled in the university education program. She feels the program with the undergraduate students most valuable.

Attempting to give the future teachers the greatest exposure to child development orientation, the student teacher program was divided into two major divisions, preparatory and elementary. Those two divisions were subdivided again into four groups: babies-toddlers, threes to fives, primary, and upper elementary. Each student teacher chooses to major in one quad and minor in another and during the student-teaching semester spend some time in each quad.

Their duties were hierarchical during the semester, culminating with independent handling of the groups of students. 
During the entire semester the students were also enrolled in a seminar class which allowed them to address the problems they were encountering.

An additional feature of the training is a one-to-one relationship between the teacher in training and an individual student in which the traditional case study is expanded so that there develops an informal relationship, which includes tutorial work, work with family, special outings, and other activities.

of the entire program Dr. Caldwell states:

In its program design the school links together early childhood education and elementary education, education and day care, education and research, and the home and the school. Each of these linkages forms a symbiotic relationship in which each component enriches its opposite. Although keeping it all together has not been easy, one could hardly claim that it has been truly difficult.

In conclusion, Dr. Caldwell states a philosophy of education which seems to have solved the problem of "discontinuity." :

Before being promoted out of the school, it is hoped that each child will have acquired a love of learning, will know how to adapt to group experience, will have mastered thoroughly the rudiments of reading and mathematics, will have experienced a cultural milieu rich enough to enable him to meet all subsequenct school experiences without apology, and will have made substantial progress toward becoming a responsible citizen. Similarly, it is hoped that each child's family will have realized that education is not something that is done for a child by a school system but rather is a continuing process in which 
the child, the parents, and school, and the community work cooperatively toward the goal of further development for all who are involved in the process.

Dr. Caldwell calls Kramer School "a prototype of a school for tomorrow which has the good fortune to be in operation today" (Braun, 1972, p. 385).

\section{Early Childhood Education in the ' 80 's}

Lavatelli (Evans, 1971) in the introduction to the book Contemporary Influences in Early Childhood Education states that the sixties might be called The Decade of Early Childhood Education. Fallon (1973) felt that the seventies were to be the decade in which early childhood education was to have as much development as any other level of education.

Even a cursory investigation of the large amount of research produced by the several disciplines concerned with early childhood education would tend to support Lavatelli and Fallon. Funding was easily available and plentiful and with the push for compensatory education, politicians found early childhood education funding to be good public relations.

However, Robinson (1982), comparing her 1981 survey of early childhood education to her 1974 survey (Robinson \& 
Robinson, 1975), indicates a less optimistic outlook by the state directors of early childhood education. They wonder where all the money for programs has gone. Using the narrow definition of early childhood education, pre-K and kindergarten, Robinson asked directors in all 50 states for information about these programs and prospects for expanding early childhood education programs in the future. She found the following:

A. In 1981,29 states offered all students who requested it the opportunity to attend kindergarten. Thirty-eight states provided kindergarten service to $55 \%$ or more of their students. Only New Hampshire, Alabama, and Mississippi provided kindergarten to less than $50 \%$ of the eligible population.

B. Though a majority of parents have appeared to accept kindergarten as an integral part of schooling, only florida has enacted legislation to lower the compulsory school attendance age from 6 to 5. In another state, Virginia, parents must inform the school if their children will not be attending kindergarten.

C. There is a wide fluctuation in time spent in school, from Vermont having two-hour-a-day classes to Hawaii, with a 6-hour-a-day class.

D. Teacher credentialing also has wide variations. Some schools hire teachers without degrees. A majority of teachers have bachelor's degrees and other school systems prefer teachers with advanced degrees.

Robinson found that in 20 states the state Directors responding either did not answer or answered negatively questions dealing with future expansion of programs for young children. 
Alabama, Arkansas, Louisiana, Mississippi, and Georgia are focusing specifically on expanded programs for kindergarten to be phased in over a four-year period.

Program expansion in five states will focus entirely on serving handicapped children. In Kansas, a bill to lower "school age" to birth for the handicapped was introduced into the ' 81 legislature.

Nineteen states are moving cautiously toward providing educational opportunity for children younger than five; Oregon is among these.

In Delaware the legislature passed a bill to provide education for preschoolers with mental and physical handicaps.

In 1980,10 school districts in Oklahoma received one-year grants for programs for four-year-olds.

Robinson concludes her article with:

Belief in the benefits of early childhood education remains strong. But cut-backs directed toward all levels of education and failure to realize the goals of the mid-Seventies have clearly dampened the enthusiasm of many early childhood educators. Nevertheless, even though all the programs I have described here are tentative, States that have led the way in previous educational innovations are now examining the facts and finding support for programs for young children. (Robinson, 1982, p. 140) 
CHAPTER III

RESEARCH AND PROGRAM FUNDING (1965-1984)

\section{Overview}

On page 296 of the book Toward Improved Urban

Education (Lutz, 1970) is the statement:

The ESEA may be one of the most dramatic pieces of existing legislation of significance for urban education, but it is not the only one.

The catalogue of federal assistance programs compiled by the Office of Economic Opportunity lists 459 federally sponsored activities dealing with domestic problems. In the specific instance of school aid the case is no more simple. During the five years of the Johnson administration alone, Congress enacted 60 pieces of education legislation. This has resulted in 111 federal education programs costing approximately $\$ 13$ billion annually. The matter is further complicated by the fact that these programs are administered by some 42 executive branch departments, agencies, and bureaus. (p. 296)

The funding described in this paper is a brief description of the major funding sources used by the Portland Public Schools from the inception of the Model Schools Program to the present. Elementary and Secondary Education Act (ESEA)

Overview

The Elementary and Secondary Education Act of 1965, signed into law by President Lyndon B. Johnson, benefitted 
most the urban classroom. The law, which initially channeled more than one billion dollars into the nation's classrooms, was designed to provide compensatory education funding for those students who were considered disadvantaged. It consisted of five titles (American Education, 1965).

Title I

Title I gave financial assistance to local educational agencies for special educational programs in areas having high concentrations of low-income families.

When the law was enacted the formula for figuring the amount each school district would receive depended upon two factors :

1. The average annual current expenditure per school child in the entire state;

2. The number of school-age children in the district from families with annual incomes of less than $\$ 2,000$ annually from the program of Aid to Families with Dependent Children.

One half of the first, multiplied by the second, would be the amount for which a local district would be eligible.

This title had its philosophical basis in the idea that there is a close relationship between poverty and the 
lack of educational development. Because of the flight of upper income families from the central cities the act addressed the issue that school districts which needed the most funding were the least able to afford it (American Education, 1965).

The federal program allocated the monies to the state educational agencies, which had full authority over seeing that the purposes of the Act were carried out. The State then accepted proposals from local districts. A district had to develop its own plan for upgrading the education of deprived children and submit it to the state for approval or disapproval. The state would then take into account such factors as the size of the program, its quality, and its promise of success.

The State of oregon's estimated allotment under Title I for fiscal year 1966 was $\$ 7,893,807$. Title I was the primary title used by the Portland Public Schools to finance its Model Schools program.

Title II

This title provided for library resources, textbooks, and other instructional materials. Oregon's allocated funds for 1966 were $\$ 975,757$. 
Title III

This program, addressing the issue of the arts, sciences, and other life enrichment areas, provided for supplementary educational centers and services. The program served three basic functions:

1. To improve education by enabling a community to provide services not available to children living there.

2. To raise the quality of educational services already offered.

3. To stimulate and assist in the development and establishment of exemplary elementary and secondary school educational programs to serve as models for regular school programs. (pp. 17-18)

Oregon's allocated funds for 1966 were $\$ 1,067,258$.

\section{Title IV}

This title addressed educational research and training. It provided for construction and programs of national and regional laboratories. A center at the University of Oregon studied the structure of schoolcommunity relations and the way educational policies are formed and decisions are put into effect (p. 80). The separate states were not allocated funds for these projects.

Title V

This title addressed the strengthening of state Departments of Education. Primarily it was involved with 
the development, improvement, or expansion of programs to make the state Department more effective. Oregon's allocated funds for this were $\$ 267,391$.

\section{Operation Head Start}

Another facet, though peripheral, of Portland's Model Schools Program is perhaps the most famous of the federal programs.

In 1964 the federal government asked a panel of child development experts to draw up a program to help communities overcome the handicaps of disadvantaged preschool children. In a report which later became the blueprint for Project Head Start, Dr. Robert Cooke, then Chief Pediatrician of Johns Hopkins Hospital and chairman of the panel wrote:

There is considerable evidence that the early years of childhood are a most critical point in the poverty cycle. During these years, the creation of learning patterns, emotional development, and the formation of individual expectations and aspirations take place at a very rapid pace. For the child of poverty, there are clearly observable deficiencies in these processes, which lay the foundation for a pattern of poverty throughout the child's entire life. (U. S. Dept. of Health \& Human Services, 1983, p. 1)

From its inception in 1965 to 1969, Head Start was under the jurisdiction of the office of Economic opportunity. In 1969, Head Start was moved to the office of Child Development in the U. S. Department of Health, 
Education, and Welfare. It has now become a program within the Administration for Children, Youth, and Families at the Department of Health and Human Services.

The program is administered by 1262 community-based organizations, community action agencies, other nonprofit organizations, and public school systems. Grants are awarded by the Health and Human Services Regional office.

From its Staff Training and Development component, Head Start has provided a most important piece of credentialing in the community colleges. This is the Child Development Associate Certification.

From the beginning the federal government realized the strong innovative components of the Head start Program and from the $\$ 96.4$ million in fiscal 1965, the appropriation for it has grown $\$ 912$ million in fiscal 1983.

Project Head start is now authorized by the Omnibus Budget and Reconciliation Act of 1981 (PL 97-35). The current authorization will expire september 30, 1984.

\section{Project Follow Through}

Project Follow Through was passed into law in 1967 and placed under the office of Education. Here the effort was to provide Head start youngsters with a sustained high level primary school environment. 
Emergency School Aid Act (ESAA)

Title VII of the Emergency School Aid Act provided partial funding for the Portland Public School's Voluntary Administrative Transfer Program. ESAA was passed in 1972. one of its major goals was to aid the facilitation, and elimination of, minority group separation.

\section{Equal Education Opportunities Act (EEOA)}

The Equal Education Opportunities Act was passed by Congress in 1974. Through this act, Congress declared it to be the policy of the United States to "insure that all children enrolled in public schools are entitled to equal educational protection without regard to race, color, sex or national origin" (City Club, 1980, p. 342). The monies were used for, among others, busing, developing magnet schools, closing inferior schools, and opening new ones.

\section{Model Cities Funding}

Under Ordinance No. 129365 (Ordinance \#136693, City of Portland, Oregon, June 5, 1973) the City of Portland entered into a contract with the Department of Housing and Urban Development of the federal government whereby funds were made available to the City to conduct a Model City program. The Portland Public School District, under a 
proposal submitted to the City of Portland, was able to share in funding and carried out a preschool program. It was funded for the first year, June 16, 1971-June 15, 1972, for $\$ 109,781.00$. The Portland Public Schools contributed $\$ 11,016,00$. It continued to be funded throughout the balance of the Model Cities Program through June 1974.

\section{Oregon State Disadvantaged Child Act}

One of the funding sources to meet the problem of "municipal overburden" was the Disadvantaged Child Fund, first appropriated by the oregon Legislature in 1967. By 1977 it provided $\$ 1$ million annually to assist in the education of disadvantaged children. In 1981 it was funded at $\$ 1,020,000$ for the following two years. Besides providing funds for additional resources, as did Title $I$ of ESEA, it supported The Voluntary Administrative Transfer Program. 
CHAPTER IV

THE PORTLAND PUBLIC SCHOOLS

History from 1851-1964

Introduction

The Portland Public School 1 district traces its origins to November 15, 1851, when a group of citizens of Portland, eight years before statehood, banded together to establish a free school. On December 15, 1851, the doors opened on Portland's first public school housed in a rented building at Southwest First Avenue and Oak street. The school had a population of 20 students, all of them white. The school had a staff of 1 and a $\$ 1,000.00$ budget. The first term of six weeks was followed by a second six-week session. In $1883 \mathrm{Mrs}$. Caroline Dunlap opened a private kindergarten in an unused engine house on Glisan street. It closed in 1887.

Portland's Black, American Indian, Mexican-American, and Oriental children were not included in the first schools. They were not included, either, in the next three schools which were opened in Portland in 1852, 1858, and 1866. However, in 1867 the Portland School Board defeated a motion to allow Black students into its regular 
schools, but allocated $\$ 800.00$ to help build a separate school for them. The school opened in late 1867 with Abbie S. Young, a Black woman, as the first teacher. Finally, in 1871 the district began admitting Black children into its regular schools and closed the Negro school. This began a long period of a pattern of neighborhood schools which largely persists to this day. Part of that pattern of neighborhood schools was the kindergarten. The September 9, 1917, issue of the Portland Oregon Sunday Journal reports the opening of the first three public school kindergartens on september 4, 1917. (See Appendices B and C.)

By 1940 only 1,931 residents of Portland were Black. Then came World War II and Blacks were drawn to Portland, largely because of the employment available at the Kaiser Shipyard.

Parenthetically, it might be stated that Portland, Oregon, under the auspices of the Henry J. Kaiser family, created, under the direction of now internationally known Dr. James Hymes, one of the most far-reaching and innovative programs for young children and their families yet devised. (See Appendix D.)

Though the program ceased at the end of World War II, one might speculate that that program had helped create an attitude of receptivity on the part of the citizens of 
Portland to the value and benefits of an enriched early childhood experience.

By 1950 the number of Blacks in Portland had grown to 9,525--an estimated $400 \%$ increase from 1940. And still the children went to neighborhood schools. They were "separate but equal" as interpreted from the plessy vs. Ferguson decision of 1896. The area in which the neighborhood was, and still is, is Northeast Portland. In 1959 the area west of Northeast 18th Avenue between Northeast Killingsworth and the Banfield Freeway was predominantly Black.

In 1947 Portland did recognize the problem of a minority. A Teaching English as a Second Language (TESL) program was started and sited at Lincoln High School.

In 1954 when Supreme Court Justice Earl Warren, in delivering his opinion on the Brown vs. the Board of Education of Topeka, Kansas case, concluded that in the field of public education "separate but equal" has no place, there was no perceptible ripple in Portland. In fact, in a 1957 report by the City Club of Portland, titled "A Report on the Negro in Portland: A Progress Report 1945-57," and noted by the Schwab Report (p. 92), the school system was mentioned only in passing. It noted only that there was a concentration of Blacks in 
some Portland schools as a consequence of residence, not by design.

The first ripple on the peaceful waters of the Portland school scene was a protest in 1956 by Henry Ward, a prominent Black leader, who opposed the construction of Eliot school. Ward predicted that it would become racially isolated as soon as it was opened. He was ignored. It had a student population which was in excess of 908 Black for several years.

By 1960, Portland's Black population had grown to 15,636. By this time the primary Negro residential area would expand north to Northeast Killingsworth and south to the Banfield Freeway. The expanded area, commonly known as "Albina," would house $78 \%$ of Portland's Negro residents. Then, in 1962 the local chapter of the NAACP studied the Portland schools. In its report to the school Board it made no specific recommendations but noted that segregation created a sense of inferiority among Black students. In the fall of 1962 the national office of the NAACP studied the Portland public schools and made two specific recommendations. They were: (a) where two adjacent school areas serve a Black neighborhood and a White neighborhood, the two school areas should be combined with one school offering primary grades and the other offering elementary grades, and (b) when new schools are constructed, they 
should be built between Black and White neighborhoods so as to bring about desegregation through establishing new attendance areas.

Neighborhood School Concept

In 1962 the neighborhood school concept was complete in Portland with few exceptions. Transfers from one school to another were carefully controlled and only for special reasons. Before the rapid changes in the economic patterns of the city, transfer from one school to another was quite lenient. In 1962, in order to prevent great numbers of students from shifting from one school to another, only hardship cases were allowed transfers. For example, transfers were allowed if both parents were working and after school child care was available in another attendance district, or the child had medical or emotional problems documented by a doctor.

Also, at grade school level, transfers might involve students who were transferred to schools outside their neighborhood in order to provide special classes for children with handicaps.

\section{Special Supportive Programs}

In a report by the Department of Research and Measurements of the Portland Public Schools (PPS, 1963), the following handicapping conditions were listed as those 
for which there were programs in the Portland Public Schools :

Obvious Handicapped Conditions

Physical Handicaps. Orthopedic or cerebral palsy, $\frac{\text { ages 3-16. }}{\text { ages }}$

Emotional or physical handicaps. Home instruction for 135 elementary children beginning at age 6 .

Speech correction and hard of hearing. Moderate to severe handicapping. Available in 54 of the elementary schools.

Deaf. Served approximately 60 children of preschool and school age. Transportation was provided for this program.

Blind. Braille instruction at home and school.

Partially sighted. Special help and materials in regular classes.

Mental retardation. Academic and fundamental skills taught to children ages 8 and up.

Health and Social Services

Health services. 35 public health nurses. The program was deficient in health education, vision screening, and home follow-up on school identified problems. No dental screening program. (p. 123)

Psychological services. Children referred for psychological check-ups by their school to test "ability to function effectively in school." In 1961-62 about 700 referrals a year were untested and there was no follow-up after testing because of a shortage of personnel. (p. 137)

Social workers. 24 school social workers assigned to 57 elementary schools and high schools on a rotating basis. They checked home/community factors affecting children having school problems. There was insufficient personnel to provide adequate 
level of services; follow through with parents was often unavailable; group therapy rarely undertaken; teacher coordination and follow through weak. (p. 151)

Remedial reading. Services provided for students reading substantially below their age levels. The program was found in 62 elementary schools. Service was not provided in 19 elementary schools because of lack of funds, space, and lack of interest by some principals. The most serious gap in the problem was failure to provide assistance for children having reading difficulties but who had sufficient aptitude to meet the program's criteria. "Reading is regarded as basis to learning by practically all Authorities." (p. 59)

In his report to the Schwab Committee (1963), Dr. I. E. Winters cited examples of Portland's "broad, rich, and varied" school programs in which the district was seeking to meet the needs of all children:

1. The Educational Enrichment (EE) or gifted child program. This served children from grades 4-12.

2. The Mentally Retarded Program (MR) for children from ages 8-high school.

These were the special programs to meet the special needs of children in the Portland public schools through 1963. They addressed the issues of the physically, emotionally, and mentally handicapped and the gifted student. They were not concerned with the effect of social and economical disadvantage nor the importance of the early years. 
Portland Citizens Committee on Racial Imbalance

In early 1963 desegregation of the Albina area schools was advocated by a self-starting group of citizens calling themselves the Portland Citizens Committee on Racial Imbalance in the Public Schools. The Committee was headed by the Reverend Paul Wright, the minister of the First Presbyterian Church, who served as chairman of the committee. The committee was composed of 100 citizens. As Reverend wright explained, the committee was "drawn from all walks of life and from all races, creeds, and political persuasions." He said that "the committee shares a common concern over racial imbalance in some of our public elementary schools" (PPS, 1981). He listed six schools which were seriously imbalanced. They were Eliot, Boise, Humboldt, Highland (now closed), and Holladay (now closed). They approached the Board of Education with the concern about de facto segregation in the schools (PPS, 1981).

\section{Committee on Race and Education}

(The Schwab Committee)

In the summer of 1963 the Board created a special commission to examine de facto segregation and other concerns of racial isolation in the schools. This committee was called the Committee on Race and Education. Because it was chaired by then Multnomah County Circuit 
Judge Herbert M. Schwab, the committee came to be known as the Schwab Committee.

The Committee membership included 17 businessmen, 11 educators, 5 attorneys, 4 labor representatives, 2 clergymen, 2 doctors, 1 civic organization representative (The Urban League), I housewife, and I television commentator, who later served as Governor of oregon. Five of the 46 members were Black (PPS, 1981, p. 55).

The committee was charged with finding the answers to three questions:

1. Does the Portland School District, to any extent, deprive children of one race of educational opportunities equal to those of other races? If so, what corrective steps should be taken?

2. What might be done to improve achievement of students in culturally deprived areas of the city in meeting the educational objectives of this school system?

3. What might the school system do through its educational process to eliminate unreasoned prejudice in the minds of children of one race against persons of another race? (PPS, 1981)

During 1963-64, while the Schwab Committee was preparing its report, the school district would have: $--79,581$ students, of whom 5,033 or 6.38 would be Black. 
--106 neighborhood schools, of which 10 would be high schools, 73 elementaries, 22 primaries, and 1 intermediate (PPS, 1981).

"Race and Equal Educational Opportunity in Portland's Public Schools" (The Schwab Report)

On November 16, 1964, the committee delivered its findings "Race and Equal Educational Opportunity in Portland's Public Schools" to the Board of Education. The report centered on two themes: (a) compensatory education and (b) reduction of concentrations of minority children (PPS, 1964).

Though one theme cannot be separated from the other, actions by Portland Public School District $I$ in succeeding years allow us to examine the first theme in light of our purpose.

The Schwab Committee, holding to the idea that the neighborhood school concept was sound and preferable to any other system, produced the following conclusions relating to compensatory education (PPS, 1981, p. 37):

1. Portland's schools were not providing children of all races with equal educational opportunities.

2. The schools must deal with the effects of a child's total environment on his or her development and ability to learn. 
3. Since the quality of education is deficient in schools with disadvantaged students, education must be upgraded for such students.

4. Substantial numbers of disadvantaged children, concentrated in a limited number of schools were receiving an education unacceptable in quality, achievement, and effectiveness.

5. The residential concentration of Negro residents, because of population shifts, contributed to development of disadvantaged and overcrowded schools.

6. While disadvantaged children were both Caucasian and Negro, many reasons, including racial isolation, produced a higher percentage of disadvantaged Negro children.

7. The neighborhood school concept was sound and preferable to any other system.

8. Experience elsewhere indicated that indiscriminate dispersal of students on a quota basis was questionable educational policy and was disruptive.

9. Voluntary transfer of children from their neighborhood schools to fill existing vacancies in other schools should produce favorable contacts between children of different races and backgrounds.

10. Since the world was multi-racial, it was essential that the school system create contacts among children of all races to accustom one to the other on favorable terms.

11. While a school system cannot alter the inherent capacity of a child, it can and must deal with the effects of a child's total environment on his or her development and ability to learn.

12. Since the quality of education is deficient in schools with disadvantaged students, means must be taken to educate such students. 
13. The school system must take educationally sound remedial measures to alleviate racial isolation and to supply all children with a sense of common acquisition of our cultural heritage. (PPS, 1964)

Recommendations

The Schwab Report, using the broad definition of early childhood education, the ages of birth through eight years, chose, though at the upper end of the age range, to attend to the plethora of literature available about the early years of a child's life and to direct its energies and funds toward that direction.

This report has been a cornerstone of the Portland Public Schools' actions from its inception to the present and is still referred to in relation to actions taken by the Board of Directors.

The Committee made six major categories of recommendations, among which was the creation of a Model School Program. The balance of this chapter will be concerned with that program and the events which had their basis in that program. (See Appendix E.)

\section{Model Schools Program}

\section{Designated Elementary Schools}

This recommendation sought a six-year intensive educational effort in from 6 to 10 elementary schools where 
achievement levels were significantly below the districtwide average and where there was a high incidence of social and learning problems. The nine elementary schools listed were Buckman, Boise, Eliot, Humboldt, Highland, Holladay, Irvington, Sabin, and Woodlawn. These schools were all in predominantly Black residential areas (PPS, 1981).

It also called for the program administrator to be directly responsible to the Superintendent of Schools; a teacher-pupil ratio of 1-20; withdrawal of upper-grade pupils to other facilities with transportation furnished; establishment of free voluntary preschools for disadvantaged children aged 3 and 4 ; cooperation with external private preschools; additional funds for field trips, supplemental materials, and staffed libraries; enlistment of parents and older students as tutors; full-time school nurses, community agents, and other support personnel; a voluntary administrative transfer program to and from other Portland schools with transportation furnished; paid intensive and continuous special training for teachers; cooperative programs with colleges and universities (PPS, 1981).

The Voluntary Administrative Transfer Program

The Committee addressed attendance policies as a vehicle for relieving the concentration of Blacks in the 
schools. It suggested that the Voluntary Administrative Transfer (VAT) program be available for all students if vacancies existed at other schools and if the transfers did not upset environmental or racial balances.

Administration of Program.

With the adoption of the Model Schools Program by the Board, Dr. Melvin Barnes, Superintendent, addressed himself to the issue of an administrator.

Superintendent Barnes nominated $\mathrm{Mr}$. Harold Kleiner, principal of Grant High School, for the position of administrator, with rank of Assistant superintendent of the Model School Program. (PPS, 1981). In a meeting before the Board, Dr. Barnes stated:

In my judgment $\mathrm{Mr}$. Kleiner is peculiarly fitted for this assignment. For twelve years he has served as an administrator in Grant High School--five years as Vice-Principal and seven years as Principal. No one of the administrative staff is more highly respected for his competence, conscience, and the zeal with which he devotes himself to education. I believe he has the energy, sensitivity, and integrity that this unique job demands. I am confident that he will do it well.

Dr. Kleiner's specific duties were as follows:

A. Selection of the schools for the Model School Program.

B. Administrative control of elementary schools in his district with authority to recommend appointment of principals, other staff members, and the 
coordination of the educational programs in the schools as recommended in the report by the Committee on Race and Education.

C. Recommendation to the superintendent of transfer of students, as contemplated in recommendations 11,12 , and 18 of the Race and Education Report, both elementary and secondary, to achieve the educational goals of the students in his district.

D. Coordination of all special educational services to his schools as well as the services of social agencies in this area.

E. Cooperation with the Division of Curriculum and Instruction in planning the instructional improvements in buildings and equipment.

F. Survey of the physical needs of the various buildings in this area and recommendation to the Superintendent of the necessary improvements in buildings and equipment.

G. Responsibility for planning, submitting, and administering a budget for the operation of the elementary schools in his district and for the achievement goals of the exploratory programs in all high schools to serve the objectives listed in the Race and Education Report.

H. Promoting the establishment of pre-school centers and provision for the coordination of these programs with the elementary schools.

On March 29, 1965, the Board appointed Willard

Fletcher as Elementary Director for the Model Schools (PPS, 1981, p. 64).

Financing.

A compelling issue regarding the report was financing. While praising the report and supporting its major recommendations, Dr. Barnes had costs on his mind. 
He noted that the report "assures that its implementation will be expensive" (PPS, 1981). It is a fact "to be faced." Dr. Barnes said that the added services required by the recommendations will increase the school budget and, he said, "to translate the recommendations into action will require some funds not now in sight. Nor can the district," Barnes continued, "develop new programs at the expense of others deserving the continuing support" (PPS, 1981).

While no accurate cost estimates are possible at this point, Dr. Barnes conjectured that "personnel to reduce teaching loads, to staff new programs, to offer new services would alone cost upward of one-half million dollars" (PPS, 1981). Dr. Barnes had grossly underestimated his monies. Outside forces, in the form of Lyndon Johnson's Great Society would provide funds in abundance for the project, as would the 1965 State Disadvantaged Child Act.

The chart on page 81 outlines expenditures from local, state, and federal resources for 1965-1969.

Reorganization of the District

By the time the Committee on Race and Education had completed its study and reported to the Board of Education on November 16, 1964, the District had come a long way from 


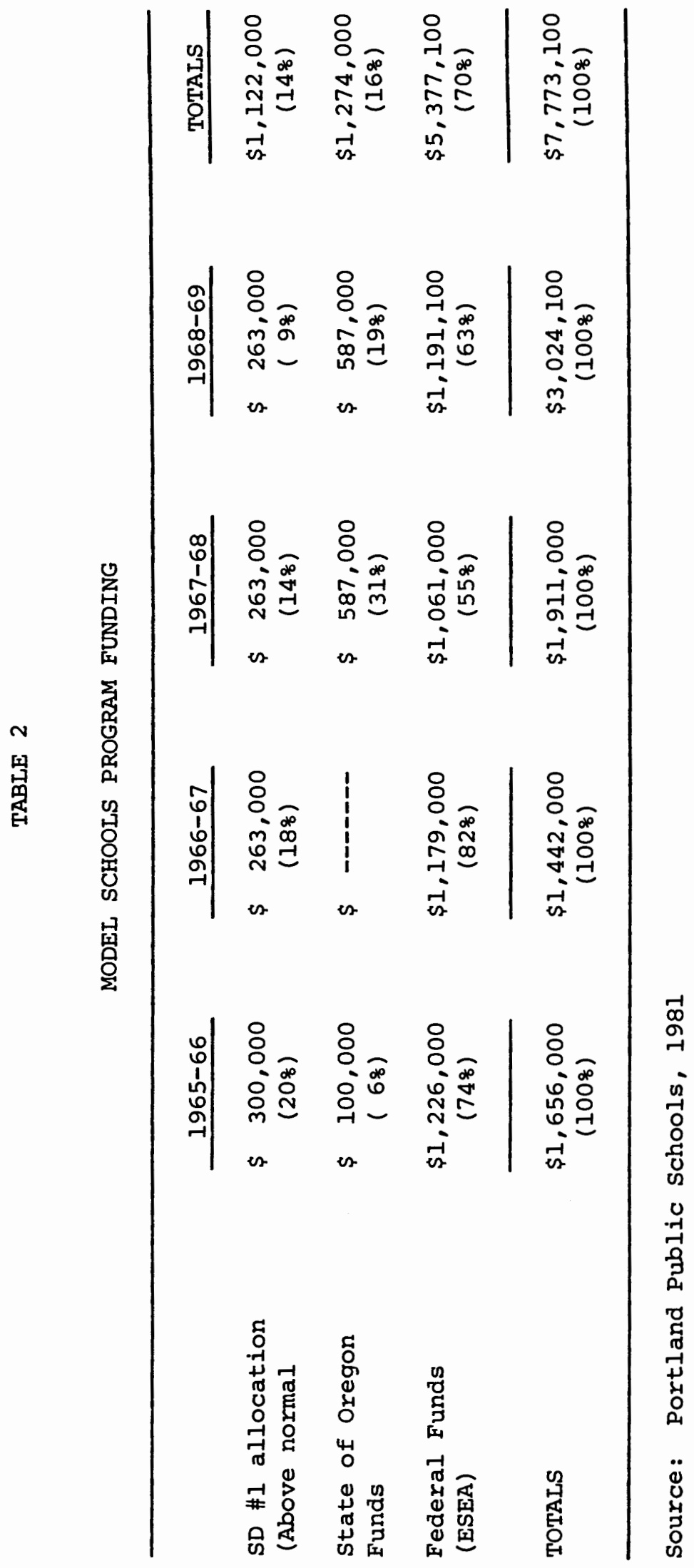


its beginnings on December 15, 1851, almost one year to the day before The Oregonian published its first edition in December 1850 .

In effect, the 1964 study launched a new era of progress in education in Portland. Though couched in terms such as racial balance, integration, compensatory education, and disadvantaged children, a new era in attention to the young child was beginning and exists unto this day.

Though the Model Schools Program seemed a simple plan on the surface, it affected and still affects the entire structure of the District.

On January 28,1965 , on the recommendation of Superintendent Barnes, the Board of Education reorganized the entire school district into seven subdistricts-two high schools and five elementary. Elementary Area II was the area in which the Model School sites were (PPS, 1981).

The supervising offices of the new areas were to be located in the area of the schools which they supervised.

The 1965-66 School Year

In the Portland Public School publication, School Bulletin, for September 1965, Dr. Melvin Barnes, Superintendent of Schools, in his column "From the Bridge," noted that Portland now had a budget which exceeded $\$ 46$ 
million and more than 3,500 teachers (p. 1). Dr. Barnes could not know that his comments were really a prelude to a second beginning in the Portland Public Schools. Dr. Barnes indicated in the article that curriculum changes, new courses, and other efforts had been made for the 1965-66 school year. He noted that during the summer there had been renewed efforts to make instruction more realistic for slow learners and for pupils who were educationally handicapped because of an impoverished environment. He also noted that groundwork had been laid for the Model Schools Program. He also indicated that Operation Head start classes during the summer had introduced hundreds of children to the idea of education (PPS School Bulletin, 1965).

The groundwork must, indeed, have been well laid as in October 1965 the state Department of Education gave approval to an ESEA proposal prepared by Assistant Superintendent Norman Hamilton and Clifford Williams, Director of Special Curriculum Projects The amount awarded was $\$ 1,940,153$, a fully-funded amount for which no matching money from Portland was needed. The bulk of the elementary money, $\$ 1,250,000$, was channeled into the Model Schools program. The use of the money included transportation to relieve enrollment pressures, employment of teacher aides, family education, psychological and social 
services, extended days, Saturday classes, and summer school (PPS, 1965).

Parenthetically, it might be stated that the Head Start Program was sponsored by the Portland Public School District, unlike most programs, which are sponsored by community agencies. It is, to this time, still sponsored by the school district and is an integral part of the district. It is, however, not housed at any of the ECE sites but in a separate facility.

In February of 1966, the School Bulletin (PPS, 1966) reported that "more teachers and teacher aides, more reading specialists, speech therapists and social workers, more tutoring and extended day programs, more new curriculum materials and audio-visual equipment--that is what Portland's Model School Program is all about" (p. 1). The goal? To improve attitudes, achievements, and goals of some 6,000 youngsters. The article goes on to indicate that the teachers were working enthusiastically at achievement--particularly in reading--at the halfway mark of the first year of this pilot program.

Also in the Bulletin, Dr. Barnes, in his column "From the Bridge," listed the qualities he felt necessary to be a good teacher for the disadvantaged: 
Organizational Skills

Imagination to use wide variety of approaches and techniques

Courage to establish standards for the child in listening, speaking, behaving, learning, and character development

Empathy which encourages growth and confidence

\section{7--The Early Childhood Education Center}

1967 brought an expansion of the Model School Program and the beginning of the now present term Early Childhood Education Center (ECEC). Holladay Elementary School reduced its instructional levels to kindergarten and became the first district-wide ECEC and became the first school to offer the federally funded Follow Through program to reinforce Head Start's students through grade 2 .

1968--Report on the Model Schools Program

In an August 1968 report to the Board of Education entitled "Model Schools Program" and prepared by the office of the Superintendent, Dr. H. A. Kleiner, Assistant Superintendent, in a status report of the Model School stated the following:

The objectives of the Area II Schools generally are the same as those in the other Portland Public Schools with special emphases and increased effort given: 
1. To improve classroom performance in reading.

2. To improve classroom performance in other skill areas.

3. To improve childrens' background and understanding of the world in which they live.

4. To improve the childrens' self image.

5. To change in a positive direction their attitudes towards school and education.

6. To raise their occupational and/or educational aspiration level.

7. To increase their expectations of success in school.

8. To increase experiences that help children appreciate their culture and develop increased understanding of their relationship to other people.

9. To provide integrated educational experiences for more minority race children.

10. To help children conduct themselves appropriately in various social settings.

11. To improve the physical health of the children.

12. To increase parent understanding of the school's role and enlist parent support in the interest of their child's success. (PPS, 1968)

The reduction of class size was discussed. Dr.

Kleiner indicated that it was being accomplished by the following:

(1) Open enrollment through which 185 children were attending schools in other areas of the city where room was available, (2) administrative transfer of 425 children with their parents' approval to 30 other 
elementary schools where room could be made available, and (3) utilizing all space possible within existing buildings for instructional purposes. In addition to providing in excess of 600 children more integrated educational experience, the transfer programs had the following impact on the Model Schools' class size.

TABLE 3

CLASS SIZE

\begin{tabular}{lrrc}
\hline School & Total & $\begin{array}{c}\text { Average } \\
1964-65\end{array}$ & $\begin{array}{c}\text { Class Size } \\
1967-68\end{array}$ \\
\hline Boise & 941 & 29.2 & 20.3 \\
Buckman & 706 & 30.7 & 25.0 \\
Eliot & 344 & 25.6 & 21.0 \\
Holladay & 301 & 27.6 & 19.4 \\
Humboldt & 352 & 28.9 & 24.1 \\
Irvington & 757 & 29.0 & 27.1 \\
King & 1013 & 29.2 & 24.1 \\
Sabin & 683 & 29.1 & 26.4 \\
Woodlawn & 805 & 30.9 & \\
\multicolumn{1}{c}{ Total } & 5902 & & \\
\hline
\end{tabular}

In addition to regular staffs in the schools, a number of specialized personnel were available to help the students. They were:

Reading specialists. Worked at primary grade levels with regular teachers in planning the reading instructional program and in conjunction with teacher during the day with small groups of students allowing much more individual attention. 
Instructional consultants. Helped many teachers with instructional programs, and in discovering more effective ways to meet diverse needs of students.

Teachers aides. Assumed many responsibilities, checking childrens' work, reading stories, etc. and generally planned more individualization for students. The teachers aides also increased the number of adults able to encourage and affirm children in their learning activities. An increasing number of aides had been employed from the neighborhood and a training program was developed for in-service training.

Teacher corps. Through a program funded by the United States Office of Education, Portland qualified for 21 teacher corps cadets who were college graduates but had no teaching experience. These individuals assisted teachers in classes, tutored, and worked with children having special work needs. While doing this, they were taking university classes. At the end of this time the teachers corpsman had earned a master's degree and was certified as a regular teacher. The teacher corps was comprised of individuals especially interested in working with deprived children. 
Community agents. Had responsibility for strengthening relationships between the school and the home. By being in touch with parents they attempted to increase the parents' involvement in the school. The community agent also attempted to involve the children in community activities that would enhance their learning experiences, such as scouting, park programs, "Y" programs, etc. They attempted to assist parents to engage in appropriate adult education, to use the community resources to help with such needs as clothing and eyeglasses for the children.

Volunteers. Hundreds of volunteers helped in the schools in all manner of activities. The Portland council of Churches sponsored a program, Volunteer Educational Assistants Projects (VEAPS).

Tutors. Buses were chartered to bring 30 or more volunteers per week from local colleges several afternoons a week to tutor individual children after school. Saturday mornings found Lake Oswego High School students at Boise School participating with more than 60 youngsters. There were children in various school activities such as reading, games, library, physical education, and discussion groups. The report also stressed an important facet of the Model School Program. This was the broadening of 
children's horizons and increasing their aspirations. Some of the experiences designed to do this were:

Field trips. These included numerous trips to places where children could see and learn about business and industry in Portland. In 1967, 17,000 pupil trips were made to 75 places.

An extended day program. This program gave remedial, enrichment, and recreational opportunities to many children after school. Classes were designed to meet the interests of the children and covered a broad range of subjects. They were in a less formal atmosphere than regular school and special encouragement was given to students with the greatest social and emotional needs.

A reading improvement center. This center was in operation at Eliot School for pupils from all the Model Schools. The pupils spent two or three days at the center undergoing extensive evaluation and diagnosis of reading needs to determine an appropriate program with varied materials to be used by the pupil under direction of his homeroom teacher. Children at the fourth grade level with extreme reading deficiency spent a half day for a period from six to twelve weeks at the center receiving intensive assistance with a variety of specialized reading material. 
The average gain during a twelve-week schedule at the reading center was approximately seven months progress for the limited number of children the center could accommodate.

Parent and adult education. Courses for the parents were offered to increase understanding of child growth and development and to strengthen parental competencies. In cooperation with the community college there were courses in basic education and adult family life.

Summer school. This was a voluntary program taken advantage of by 1,400 children. Offerings were from basic skills, on a more relaxed and individualized basis, to special interest courses.

Tutorial classes. These were developed for students who have problems with adjusting to the classroom environment because they lack emotional control. They were taught in small groups with highly programmed basis (PPS, 1968).

Early Childhood Education Head start. Though this program has always been a separate entity and has never been housed at model school sites, it was considered part of this program for young children. Head start was conducted with 808 of the funding from the office of Economic Opportunity. More than $90 \%$ of the 450 four-year- 
old children fell within the poverty guidelines established by OEO for Head start. There were six centers of two rooms each, four owned by the school district and two centers rented from churches. Each class served 20 children in the morning and another 20 children in the afternoon so that the teacher and aide worked with 40 children during the day. The aides were recruited from the area and were selected on the basis of financial need and their willingness and ability to serve children. An in-service training program was conducted for the aides. About three-fourths of the children in the program were Negro and the other quarter were Caucasian and other races. Children attended class either three hours in the morning or three hours in the afternoon. Classes included instructional activities designed for individual children and also incorporated medical and dental care as well as social and nutritional services. Again, particular emphasis was placed on parental involvement (PPS, 1968).

In the report about the Model Schools was the following telling comment about the Portland Public Schools:

The majority of school districts that have begun programs of compensatory education have made modest alterations and their gains, if any, have been modest. A few districts have permitted small groups to experiment with ideas that represent radical departure from the traditional and their gains, if any, have not been reported. The Portland approach 
has been innovative without being radical. Tried and proven procedures are used as better procedures are developed. (PPS, 1968, p. 9)

In the School Bulletin of May 1966, in an article entitled "Portland Board Nations Best Classroom Teachers Declare: $\$ 2,000$ Cash Award Coming," was the information that on May 24, 1966, Dr. Melvin Barnes and Mr. William Wyse, Chairman of the Portland School Board, were to fly to Washington, D.C., to receive the cash award and "lamp of learning" sculptures from the classroom teachers' division of the National Education Association.

The Portland, Oregon, Board of Directors had been cited for the most creative educational accomplishments during the 1965-66 school year by districts with 3,000 or more students. The basis for the award was the Model Schools Program.

The members of the panel which had chosen Portland for this award were: North Carolina Governor, Terry Sanford; Norman Cousins, editor of Saturday Review; Mrs. Jennelle Moorhead, president of the National Parent Teachers Association; Frank Stanley, Jr., associate director of education for the National Urban League; and George B. Brain, past president of the American Association of School Administrators (p. 1). 
Follow Through in the Model Schools Program

At Holladay School, the first school to have a Follow Through program, encompassing kindergarten through grade 3, 100 Follow Through children were joined by 200 other children with no Head start experience, allowing for a broad spectrum of socioeconomic backgrounds, with children from Fernwood and Laurelhurst as well as the other Area II schools. The Follow Through kindergarten children attended all day while kindergarten children not in Holladay attended regular half-day sessions throughout the year. In addition to the regular kindergarten program, the Follow Through children met in small group session to improve science understanding, reasoning, verbal skills, perceptive skills, concept development, and also to participate in small group trips. All of the children benefitted from the education specialists, and all also participated in music instruction and physical coordination activities from specialists. The quality of this Follow Through resulted in a renewal of the original 1967 grant (PPS, 1968). Because an additional grant for a new group of kindergarten children had been approved, the project would move to Eliot School in 1968. The intermediate and upper grade children would attend elsewhere to make room for nearly 500 children (PPS, 1968). 
A colorful and enthusiastic member of the Model Schools Program team was Dr. Robert Harold, the Follow Through Program's director in Portland. The Follow Through program had begun in Portland in 1967 with six kindergarten classrooms. The Portland Program was one of 30 pilot projects in the Follow Through Program in the nation. In a July 8, 1970, Portland Public School newspaper release from the Public Information Office, Harold announced that the program would serve 1,000 students starting in september and that "more are welcome." He continued that the program would include, in total, 9 kindergarten classrooms, 8 first grade rooms, 7 second grade rooms, and 6 third grade rooms. It would serve 500 former Head start children. Holladay and Eliot schools were the two schools funded by Follow Through funding. In an Oregonian article ("Eliot Affluence Sparks New Methods," 1972) Harold, also principal of Eliot School, warned that Eliot School could not be compared with other Portland elementary schools. Eliot School was receiving $\$ 530.00$ per child of Follow Through funds besides the $\$ 850.00$ amount per student allotted by the Portland Public Schools. An important element of the Portland program, according to Harold, was that it was, along with 15 others in the country, not tied to a "sponsor"; a university or 
corporation which would use the program as a testing ground for a specific teaching model ("Eliot Affluence Sparks New Schools," 1972).

Harold classified his kindergarten student population into two groups--those whom the federal government had determined disadvantaged and the "peanut butter and jelly kids" not considered disadvantaged and from stable backgrounds whose parents wished to take advantage of the enriched opportunity at the school through the Voluntary Administrative Transfer Program. He had approximately a 50-50 mix of children. In the lst through 3 rd grades about $25 \%$ of the children were "peanut butter and jelly children." Harold indicated that "our business is not integration. But I don't think we're going to solve the problems of the city until we break up economic concentration of kids" ("Eliot Affluence Sparks New Schools," 1972).

Among the benefits cited by Harold:

1. A low ratio of students to teachers and other adults- -480 children to 53 employees.

2. Aides and volunteers; high school students teaching interns, and assistants from residential Manpower and New Careers Program.

3. Extensive support services including social work, medical and dental care, frequent field trips, and additional school supplies.

4. Extended day care.

5. Access to an instructional cable television network. 
6. A television production studio within Eliot which housed a quarter of a million dollars worth of audiovisual equipment.

7. Payment of $\$ 2$ per hour to parents for attendance at weekly group meetings to achieve involvement in their child's school experience.

8. A lending library of books, games, cassette tape players, and other materials so parents could take education home with them.

9. Paraprofessional recruited from poverty areas and given on-the-job training and college classes to move them up the pay ladder to the position of "associate teacher."

10. Follow Through kindergarten children attending full-day school while children in other Portland Public Schools going one half day.

11. Special sessions in language, concept development, and cognitive skills for former Head start children.

Harold concluded by saying that being a $\mathrm{k}-3$ school had one advantage because "in a $k-8$ school the squeaky wheel gets the grease. Here all of our work is directed at the primary grades." Linda Roy, a third grade teacher, agreed: "This is where the basic skills count, not in the eighth grade. We get them early and give them a good head of steam" (Oregonian, 1972).

\section{A Change in Administration}

With the resignation of Superintendent Barnes in 1968 to join the staff of Scholastic Magazine and the stewardship of Dr. Kleiner, the Board, realizing that it needed 
new ideas to meet the challenges of the times, set out upon a five month search for an administrator. On February 25, 1969, in a newspaper release from the Portland Public Schools' Information Department, Mrs. Mary Rieke, Chairman of the Board of Education, announced that Dr. Robert W. Blanchard, 42, a specialist by training and experience in urban school administration would be the new superintendent of the Portland Public Schools effective July 1, 1969. Blanchard was currently superintendent of schools in Montclair, New Jersey. He had earned a doctorate in Harvard University's administrative career program in educational administration. Dr. Blanchard had published widely in the field of school administration.

Mrs. Rieke stressed, upon announcing Dr. Blanchard's appointment, that he was hired after a nationwide search for a person trained and experienced in urban school administration. Mrs. Rieke indicated that the persons who had testified during public hearing on the qualifications needed for the Portland superintendency had repeatedly recommended that the school board hire a man who possessed administrative leadership characteristics.

Mrs. Rieke contrasted this with the appointment of Dr. Barnes as superintendent eight years ago. At that time the district had sought and found one of the ablest curriculum leaders in the nation. She stressed that Portland was 
now recognized as one of the leaders in curriculum in the nation but that at this time the district's needs were quite different. She stressed that it was now time to consolidate the curriculum gains in terms of leadership in the field of management and organization.

Dr. Blanchard believed that a parallel could be found between the role of a corporate president and that of a chief of school systems officer.

He commented, "I find that my own decision-making today draws more upon my background in the social sciences than it does upon my education training or experience; not unexpectedly, for education is certainly big business."

Dr. Blanchard also saw education at stage center of the political and social life of an urban community. "Because of this," he said, "training and experience of a very different kind than traditional is essential for a successful city superintendent".

Clearly, a new era had come to Portland, Oregon. The benign era of the educator turned superintendent had ended.

\section{Robert Blanchard and the Portland}

Schools for the '70's

Questions to Be Addressed

Shortly after his arrival the Board of Education asked Blanchard to address four major questions. They were: 
1. How should the School District organize for the future to equip it with the ability to better respond to the needs of students, staff, and citizens?

2. How should the education programs be organized for the '70's?

3. What additional steps are appropriate in light of the 1964 Schwab Report?

4. How could the District's education and fiscal investments in this school plant be protected? (PPS, 1981).

The second and third questions for the purposes of this paper were most important. Would the Model Schools element of the Schwab Report survive?

Recommendations

On January 21, 1970, the Board received from Blanchard his recommendations entitled "Portland Schools for the Seventies." At its meeting on March 23, 1970, it adopted Resolution 3553, among which were the following points:

1. That it is essential to strengthen the educational program in our upper elementary grades, educating grades 5 through 8 in middle schools with greater specialization of teaching staff and better instructional facilities. It is likewise desirable based upon our experience in Head Start and Follow Through Programs in recent years to establish a number of early childhood centers to provide preschool as well as primary education through the fourth grade and make such centers available on a voluntary basis to children throughout the district. 
2. The present elementary schools in the Albina area will be converted as soon as facilities permit to early childhood centers consisting of preschools, kindergarten, and grades $1-4$.

These centers will be designed for continuous progress of the students who will be transferred to the appropriate middle school when the student's achievement and maturity in the judgement of parents and school indicate he or she is ready for middle school.

3. Early childhood centers as they are established shall included students within the attendance area, together with those students from without the area whose parents request their transfer to one of the centers. Transportation shall be provided for students residing outside the center attendance areas.

4. The present kindergarten through eighth grade elementary school organization shall be changed to establish primary schools consisting of all grades through the fourth grade, and middle schools for grades 5 through 8 .

5. Central Administration: The Central Administration office shall be reorganized into three divisions: Operations, headed by the Deputy Superintendent; Systems Support, headed by an Associate Superintendent; and Management Services, headed by an Associate superintendent.

6. Administrative Areas: The present five elementary areas and the present two high school areas shall be reorganized into three administrative areas. Each area Superintendent shall serve in his position at the pleasure of the Superintendent and shall administer the schools within his area in accordance with the superintendent's instructions and the policies of the Board of Education.

Another important component of Blanchard's plan was the creation of three area citizen advisory committees, each having seven adults and two high school students as 
members appointed by the school board. Also, three staff advisory committees, each having at least nine primary, elementary, and secondary teachers as members elected by fellow teachers, would be created to provide two-way communication for the area superintendents and their instructional staffs.

\section{Early Childhood Education Centers}

In 1972-73 Holladay Primary and its ECE center would close, reducing the number of elementary Model Schools to eight. But Irvington Elementary would reduce its instructional levels to kindergarten through grade 5 and replace Holladay as the school district's second district-wide ECE and Follow Through Center.

In 1974-75 Humboldt Primary would reduce its instructional levels to preschool through Grade 3 and become the school district's third district-wide ECE Center.

In 1975-76 King Elementary would reduce its instructional levels to preschool through Grade 5 and become the school district's fourth district-wide ECE Center. Eliot Primary, an existing ECE Center, also would begin to admit preschoolers.

In 1976-77 Sabin Elementary would reduce its instructional levels to preschool through Grade 5 and become the school district's fifth district-wide ECE Center. Boise 
Elementary would develop fundamental basic skills as the first district-wide specialized elementary program. In 1977-78 Vernon Elementary would reduce its instructional levels to preschool through Grade 5 and become the school district's sixth district-wide ECE Center. Woodlawn Elementary also would reduce its instructional levels to kindergarten through Grade 5. Title I preschools would open, coming under the supervision of the Head Start Program. The school district's Extended Day Centers would be closed and replaced by an expanding number of Latch Key Centers operated in Portland schools by private nonprofit agencies (PPS, pamphlet, n.d.(a)).

\section{End of an Era}

As part of the attack on racial isolation, the Model Schools Program succeeded in reducing the size of the average class within its schools. It established the preschool program, added teacher aides and community agents, and provided better instructional material to these students.

The program also added reading specialists to each school, reduced the percentage of teachers requesting transfers from these schools, and provided the tools for involving parents in their children's education. 
The transfer program grew successfully through the '60's and continued to be an important part of the district's desegregation programs of the '70's (PPS, 1981).

The Community coalition for School Integration

The years between the Schwab Report in 1964 and 1977 were years of relatively calm desegregation. In 1977 began a period of intense turbulence brought about by a problem with Jefferson High School. During the course of this period the basic tenets of Portland's Desegregation/ Integration Program were challenged and changed.

In 1977 the Community Coalition for School Integration was formed. It was a coalition of independent citizen organizations which received some funding from the School Board, the city, and other groups. It was formed to carry the desegregation/integration issue forward.

\section{Equity for the ' 80 's}

In November 1978 the Coalition presented its report, entitled "Equity for the Eighties" to the School Board. The report essentially requested that the burden of integration be shared more equally. 
Page 4 of a pamphlet entitled "Desegregation Options, Draft II" (PPS, 1980) restates the basic philosophy of early childhood in the Portland Public Schools:

Every child is unique. The child's individuality, personality, family life, previous experience, skills and abilities must be understood, developed and guided by parents and teachers. Early childhood education programs should provide for discovering, experimenting and experiencing the pleasures of learning. There should be opportunities for stimulation of ideas, creativity, social interaction and encouragement of intellectual curiosity. Opportunities for learning through use of exploratory materials and special equipment should be available at a sufficient level to provide to each child a complete daily program. Learning experiences should be designed to give each child an opportunity for full personal development without regard to race, religion, cultural background, sex, or handicapping conditions.

It then went on to discuss the fact that more nonminority parents took advantage of the prekindergarten and kindergarten programs in the Early Childhood Education Centers than they did the programs of grades 1-4. It was felt that this fact might imply that there were three possibilities:

1. The strength of the appeal of prekindergarten education which is largely unavailable elsewhere in the District;

2. the strength of the appeal of a full-day kindergarten program which is equally unavailable elsewhere in the district;

3. the perceived excellence of the curriculum and instructional components of both programs. ( $p .4$ ) 
The desire of those working on the comprehensive desegregation program was to make offerings in grades 1-4 so special that nonminority parents would elect to keep their children in these schools through their entire Early Childhood Education period of schooling.

On April 14, 1980, the School Board adopted The Comprehensive Desegregation Plan for the Portland Public Schools (PPS, 1980). Key improvements in the Early Childhood Education Centers include:

1. smaller adult-child ratios (These changes would add approximately 7 FTE in a 500 student school.)

2. more intensive emphasis on basic skills (reading, writing and arithmetic)

3. "learning maps" which stress each child's unique style of learning

4. "continuous progress" classroom assignments which allow each child to learn at her/his own rate of speed

5. improved evaluation of achievement with an emphasis on child-parent-teacher communication

6. "learning contracts" which emphasize attainment of achievement goals for each child through joint school-home cooperation

7. special attention to the newest curriculums in multiethnic/multicultural education for each child

8. new curriculum enrichment electives for each child including science, visual arts, music and foreign languages

9. strengthened home-school ties including options for parent-teacher planning for each child's learning experiences 
10. new opportunities for parent education programs

11. strengthened staff development experiences for teachers and aides

12. the involvement of parent volunteers as tutors and the use of private homes for school related support activities (PPS, 1980, p. 10)

\section{The Matthew Prophet Superintendency}

\section{(1982-present)}

On April 1, 1982, Dr. Matthew Prophet became the Superintendent of Schools in Portland, Oregon, from a similar position he had held in Lansing, Michigan, from 1978. His Vita tells us that Dr. Prophet holds a doctorate in educational supervision and administration from Northwestern University. He spent the years from 1951 to 1971 in the U.S. Army, rising from the rank of Private to Lieutenant Colonel at his retirement.

At its regular meeting on November 24, 1982, the Board of Directors adopted Official Resolution X1632, four goals proposed by Dr. Prophet. The were:

I. Educational Effectiveness. "It is the primary goal of the Portland Public Schools to improve student achievement for all students in all schools in the district."

Activities listed were to improve support programs and services to the classrooms. Three subheadings were: 
A. Focus on elementary school service.

B. Give teachers time to teach.

C. Help students meet standards/expectations.

Also listed as an activity was to study district educational programs, alternative offerings, and special programs, among others.

II. Fiscal Effectiveness

III. Communications Effectiveness

IV. Management Effectiveness

One of Prophet's first acts as Superintendent was to realign and eliminate some staff position for financial savings.

Dr. Prophet, in a memorandum to the Board of Education on May 20, 1983 (Portland Public Schools, 1983), outlined his administrative staff realignment plan. In the 25 page memorandum there was no mention of the ECE Centers, per se. However, there was great emphasis upon delivery of services to the classroom teacher. Toward this end Dr. Prophet created the position of Director of Instruction (DOI). These positions are in a direct line from Dr. Prophet through Executive Deputy Superintendent Donald MCElroy.

Based on the theory that the principal, through his influence on the teachers in his building, can best improve the level of instruction in his building is a major factor in quality education, a plan was formed wherein Directors of Instruction would have principals under their 
supervision. The Directors of Instruction would be relieved of many of the duties of area superintendents and though they would be in Area clusters, high schools with feeder schools the DOI's would have time for the principals and time to go into the schools. Dr. William Gerald is the DOI for the Jefferson cluster, which contains Boise, Eliot, Humboldt, King, Vernon, and Woodlawn. Larry Ayers is DOI for the Grout/Benson Cluster, which contains Irvington and Sabin.

It is early in the Prophet superintendency. However, it will be of interest to observe what the future holds for Early Childhood Education Centers and Early Childhood Education in general. 


\section{CHAPTER V}

CONCLUSIONS AND RECOMMENDATIONS FOR FURTHER STUDY

\section{Conclusions}

Two major questions were addressed in this thesis. The first was:

How have the study of and teaching of young children evolved, and what effect did the massive funding by the federal and state governments have on the redefinition of the discipline known as Early Childhood Education?

Analysis of this question may best be organized within Lazerson's (NSSE, 1972) three themes which he feels dominate early childhood education.

The first theme is the expectation that schooling for the young will lead to social reform. Indeed, the first institutionalized care, that outside of the mother-child relationship, was addressed to the handicapping conditions caused by poverty. Predating Head start by a century, Froebel, Montessori, and the McMillan sisters all expressed the hope that their ministrations might give the youngsters aspirations and hope that they could take their place in society, a "Head Start" so to speak. In the United States with the succeeding waves of immigration into the country, society as a whole felt the need to deal with the young 
child as a hope of assimilating the child into society and maintaining future social order.

With the segregation/integration push of the '60's, the emphasis was still upon the disadvantaged, but the thrust had changed. There was increased emphasis upon the educationally disadvantaged and the push for programs came not from social scientists and educators but from parents of the children. These parents were not the helpless native poor or immigrants. They had roots deep in America and happened to have other than white skin. Knowing how to manipulate the political process--or at least to create enough civil discord--they made their wishes known and society had to accede to them in some manner. The desires of these parents again harken back to the early childhood education pioneers' goal that the children's aspirations be raised so that they might take their place in society or, more to the point, have their fair share of the wealth.

The second stated theme of Lazerson's, the uniqueness of childhood, has been a recurring theme from the beginning of early childhood education. As with the early pioneers, when the preprofessional proper young women of the prescientific religious and philanthropic early childhood education movements went forth, their programs were largely concerned with the "unfolding of the young." 
The child study movement began a new scientific period of study of the child with emphasis upon not merely allowing the child to develop but to create curricula which was compatible with the developmental age of the child. The cognitive psychologists, in challenging the idea of a fixed intelligence and developing teaching methods geared to the style of the learner carried on the idea of the uniqueness of the child but now addressed the children's academic endeavors.

The third issue Lazerson cites is the impact of early childhood education on the public schools.

Until the period when the universities were given the responsibility for teacher training the nurserykindergarten movement had very little impact on the public schools. Within university departments of education, the philosophical schism between the Froebelians and Progressives within the Early Childhood Education discipline began to emerge. Also, the practitioners of nursery school education, kindergarten, and the elementary teachers were in conflict. Kindergarten teachers felt that the schools were too rigid and the teaching methods were too stringent for the children. The elementary teachers felt that the kindergarten teachers were not doing an adequate job of getting the children ready for the rigors of the $3 \mathrm{R}$ 's. 
When the massive federal funding of the War on Poverty began to hit the schools in the middle of the 1960's, there was an expansion of Early Childhood Education programs.

Also, the kindergarten-primary in the public schools credentialing was being phased out in universities in favor of Early Childhood Education credentialing, which included many kinds of preprimary educational programs. This would have been a first-rate opportunity for the public schools to have redesigned programs, as did the state of California, and Dr. Bettye Caldwell with the Kramer School, to take a broad view of ECE and to make ECE an integral part of the public schools. However, this did not happen on any large scale.

The author feels that the long-held ideal of an integrated Early Childhood Education program did not happen primarily for two reasons. The first was because the practitioners of early childhood education had been warring for so long with each other about what were the parameters of ECE and disliking other practitioners--particularly if they were self-proclaimed, elitist, credentialed, public school teachers. The second was that the major of ECE theorists and practitioners were so idealistic and politically naive that they could not mobilize to gain the political power which would carry over to the time when 
funding was not easily available. Also an organized assault was not made on the public schools to make certain that those teachers who were teaching young children were credentialed to teach ECE.

It is of paramount importance to the early childhood educator to continue to keep making the state and federal legislatures and public at large aware that there has been since the beginning of the child study movement, and is now even more since the '60's and '70's, solid research residing on university library shelves stressing the importance of the early years of a child's life as the basis for the educational experience. One can only ask, if that research was valid in the 1960's and '70's, why is it not valid now? The obvious answer is that it is still valid but that the political climate has changed and, with the easing of the push for desegregation/integration and the shortage of tax monies, early childhood education has become a low priority on the agenda of legislatures. However, the disadvantaged remain and, to return to Lazerson's first theme, what will be the result for society at large?

The second question posed by this thesis was:

How has Portland School District I utilized that discipline known as Early Childhood Education during the period from 1965 to the present to meet the needs of the culturally disadvantaged in the context of desegregation/integration? 
The innovative program known as the Model Schools Program with its reorganization of the entire school district was a bold stroke. Its present Early Childhood Education Centers, a city-wide program which grew out of the Model Schools Program, are monuments to that time. However, there have been no new Early Childhood Education Centers created since the end of the 1970's, and conditions which created the Model Schools Program still exist. There are also, at present, other conditions which would seem to plead the case for more attention to the early years of a child's life--e.g., the restructuring of the concept of family, the single-parent home, mothers working outside the home, and the immigration of population from the far eastern cultures--which vary widely from American culture and even those European cultures which provided previous masses of immigrants.

In light of available child development research and the longevity of the Model Schools/Early Childhood Education Centers, why must social or economical disadvantage be the criteria for creating a solid Early Childhood Education Program taught by credentialed early childhood educators? Why not throw off the historical antecedents of early childhood education and take the next bold step and create these programs for all children? 
Recommendations

A longitudinal study of operating exemplary Early

Childhood Education programs would be valuable in providing dollar-efficient information about the value of complete Early Childhood Education programs within school districts. Would there be fewer retentions, fewer dropouts, and higher achievement scores in Portland as has been seen in research of programs elsewhere (Lazar, 1982; Schweinhart, 1980)?

This paper has not addressed itself to any attempt at assessment of Early Childhood Education Programs in the Portland Public Schools as they currently exist. This would seem to be an area for study. A study of the effects upon the lives of the students who were involved in the Model Schools Program would be of interest.

In conclusion, a quote from Lawrence Frank (Senn, 1975) would seem appropriate. He wrote in 1939, in an unpublished paper:

In medicine and psychiatry and education, in all the disciplines that are concerned with human life, there is a growing conviction that the ills, the defects, the disasters of adult life are in many cases the inevitable outcome of what has happened in the childhood of the individual. Preventive medicine, mental hygiene, and the beginnings of what has been called "preventive politics" indicate a new approach to social problems and difficulties, are all pointing to the crucial years of infancy and childhood as the time where our new scientific knowledge and our new insights and understandings may be most fruitfully applied. 
In the longer years to come it is possible that the emergence of child development resources and the diffusion of what might be called the child development viewpoint will be regarded as one of the more significant developments of the twentieth century, for here, concretely and practically, is being shown how at last man may take charge of his own destiny and begin to build the kind of organisms and personalities through whom alone the enduring human values and aspirations may be achieved. (p. 89) 


\section{BIBLIOGRAPHY}

Baldwin, B. (1922). For the study of young women. Journal of American Association of University Women, 15.

Benesch, J. (Ed.) (1978). Early childhood education: A study of twenty-seven states. Charleston, WV: West Virginia Dept. of Education.

Blackwell, J. (n.d.). The kindergarten concept: A necessary component of the educational system. Reading Improvement, 17(1), 6-9.

Bloom, B. (1964). Stability and change in human characteristics. New York: John Wiley.

Boyd, B. (1957). Prospectives on the Eliot School problem. Unpublished bachelor's thesis, Reed College, Portland, OR.

Braun, S. J., \& Edwards, E. P. (1972). History and theory of early childhood education. Worthington, $\mathrm{OH}$ : Charles A. Jones.

Bruner, J. (1960). The process of education. New York: Vintage Books.

Caruso, D. R., \& Detterman, D. (1981, November). Intelligence research and social policy. Phi Delta Kappa, 63, $183-185$.

Cataldo, C. Z., \& Salzer, R. T. (1982). Early childhood program benefits and middle class families. Child study Journal, 12(1), 45-56.

City Club of Portland. (n.d.) A report on the Negro in Portland: A progress report 1945-1957. City Club of Portland Bulletin.

City Club of Portland. (1980, May 30). Report on racial integration/desegregation issues in the Portland Public Schools. City Club of Portland Bulletin.

Clemens, C. (1981) Financing Oregon schools. Portland: office of the superintendent.

Eliot affluence sparks new methods. (1972, April 23). The Sunday Oregonian. 
Elkind, D. (1970). The case for the academic preschool: Fact or fiction. Young Children, 25.

Evans, E. (1971). Contemporary influences in early childhood education. New York: Holt, Rinehart, \& Winston.

Fallon, B. (Ed.). (1973). Forty innovative programs in early childhood education. Belmont, CA: Fearon Pub. Co.

First work of these times. (1965, April). American Education, pp. 13-20.

Fisher, L. (1908). Report of the Commission of Education. Quoted in Vanderwalker, The kindergarten in American education. New York: Macmillan.

Frost, J. (Ed.). (1968). Early childhood education rediscovered. New York: Holt, Rinehart, \& Winston.

Frost, J. (1973). Revisiting early childhood education. New York: Holt, Rinehart, \& Winston.

Katz, L. G. (1970). Early childhood education as a discipline. Young Children, 26 (2), 82-89.

Larson, v. (1974). Portland's in-service involves all professional personnel. Educational Leadership, 31, 502-505.

Lazar, I., \& Darlington, R. (1982). Lasting effects of early education: A report from The Consortium for Longitudinal Studies. Society for Research in Child Development Monograph, 47(2-3, Serial No. 195).

Lutz, F. (Ed.). (1970). Toward improved urban education. Worthington, $\mathrm{OH}$ : Chas. A. Jones.

Margolin, E. (1969). Crucial issues in contemporary early childhood education. Childhood Education, 45(9), 500-504.

Model cities funds extend Blacks' School. (1972, May 3). Oregon Journal.

Morris, M. S. (1970). The California credential story: A new specialization for teachers of young children. Young Children, 25(5), 268-281.

National Society for the Study of Education. (1907). Sixth yearbook. Bloomington, IL: Public School Publishing Co. 
National society for the study of Education.. (1972). Seventy-first yearbook (Part II): Early childhood education. Chicago, IL: University of Chicago Press.

Nieman, R., \& Gastright, J. F. (1981, November). The longterm effects of Title I preschool and all-day kindergarten. Phi Delta Kappa, 63, 184-185.

Nimnicht, G. P. (1969, December). A new state priority: Early childhood programs. Compact, pp. 3-6.

Osborn, D. K. (1980). Early childhood education in historical perspective. Athens, GA: Education Associates.

Parker, F. W. (1896). Talks on teaching. New York: E. L. Kellogg.

Piaget, J. (1966). Foreword. In M. Almy et al., Young children's thinking. New York: Teacher's college Press.

Portland, City of. (1973, June 13). Ordinance \#186993.

Portland Public Schools. (n.d.(a)). Goals for education in Portland. Portland: Office of Administrative Support. Pamphlet.

Portland Public Schools. (n.d.). History: Racial integration programs for the Portland Public Schools. Portland: Public Information Office.

Portland Public Schools. (n.d.). Racial balance. Portland: Public Information office. Pamphlet.

Portland Public Schools. (n.d.). Racial integration programs for the Portland Public Schools. Portland: Public Information Office. Pamphlet.

Portland Public Schools. (1961, september). From the bridge. School Bulletin, $52(1), 1$.

Portland Public Schools. (1963). A study of child services. Portland: Department of Research and Measurements.

Portland Public Schools. (1964). Race and equal education opportunity in Portland's public schools: Report of Committee on Race and Education. Portland: Committee on Race and Education. 
Portland Public Schools. (1965). State approves $\$ 2$ million proposal to raise achievement levels of pupils in 4 city high schools, 25 elementaries. School Bulletin, $\underline{52}(2)$.

Portland Public Schools. (1966, February). Teachers enthusiastic at reading progress of pupils in Portland's nine Model Schools. School Bulletin, $\underline{52}(6)$.

Portland Public Schools. (1966, May). Portland Board nation's best, classroom teachers declare; $\$ 2,000$ cash award coming. $\underline{52}(9)$.

Portland Public Schools. (1966, June 1). District gets go ahead for Head Start. School Bulletin, $\underline{52}(10)$.

Portland Public Schools. (1968). Model Schools Program. Portland: Office of the Superintendent.

Portland Public Schools. (1969, February 7). News release [re: collaboration with Portland on Model Cities Program]. Portland: Public Information Department.

Portland Public Schools. (1969, February 25). News release. Portland: Public Information Office.

Portland Public Schools. (1969, September). Back to school statement by Dr. Robert W. Blanchard. Portland:

Public Information Department. Radio/TV news release.

Portland Public Schools. (1969, September 2). New look marks new year: New superintendent takes charge and administrators change roles. PPS Staff Report.

Portland Public Schools. (1970, February 9). Board meeting statement by Robert W. Blanchard. Board of Education Meeting.

Portland Public Schools. (1970, June 12). Staff reorganization plan approved. PPS Staff Report.

Portland Public Schools. (1970, June 26). After 12 years as "woman on the board" Mrs. Rieke retires. Portland: Public Information Department. News release. 
Portland Public Schools. (1970, June 26). Beatty to leave "eye of the hurricane." Portland: Public Information Department. News release.

Portland Public Schools. (1970, July 8). Follow through wins federal cash. Portland: Public Information Department. News release.

Portland Public Schools. (1970, July 9). Model City residents to become teachers. Portland: Public Information Department. News release.

Portland Public Schools. (1970, October). Areas outlined. PPS Staff Report, p. 3 .

Portland Public Schools. (1970, October). Staff shuffled. PPS Staff Report, p. 2 .

Portland Public Schools. (1971, June 29). Summer activities. Portland: Public Information Department. News release.

Portland Public Schools. (1973, March). Change and challenge for education in the 70 's. Pamphlet.

Portland Public Schools. (1975, January). Comprehensive information. In PPS, Annual report (p. 9).

Portland Public Schools. (1980, January 30). Desegregation options. Draft II. Appendix. Portland: PPS.

Portland Public Schools. (1980, April 14). Comprehensive desegregation plan. Portland: Public Information office.

Portland Public Schools. (1981, September). Chronology and history desegregation/integration Portland Public Schools, 1962-1982. Portland: Office of the Superintendent.

Portland Public Schools. [1983]. '83 enrollment report. Portland: Management Information Services, Publication Services. Pamphlet.

Portland Public Schools. (1983, May 20). Administrative staff realignment. Portland: Superintendent of Schools. Memorandum. 
Portland Public Schools. (1983, November 23). District one-year objectives in educational, management, fiscal, and communications effectiveness. Item $\mathrm{X}$ 2817. Board of Directors meeting.

Portland Public Schools. (1984, April). Vita of Matthew W. Prophet, Jr. Portland: Office of the Superintendent.

Portland Public Schools and The Oregonian. (1972, March). Collection of articles on public schools.

Ransbury, M. K. (1982, November/December). Friedrich Froebel, 1782-1982: A reexamination of Froebel's principles of childhood learning. Childhood Education, 59, 104-106.

Robinson, E. H., \& Robinson S. L. (1975, April). Early childhood education: Practice outpaces theory. Phi Delta Kappan, 56, 566-568.

Robinson, S. L. (1982, October). An update of the status of early childhood education in the United States. Phi Delta Kappan, 64, 140 .

Schweinhart, L. J., \& Weikart, D. (1980). Young children grow up: The effects of the Perry Preschool Program on youths through age 15. Ypsilanti, MI: High/Scope Press.

Senn, M. (1975). Insights on the child development movement in the United States. Monographs of the Society for Research in Child Development, 40 (3-4, Serial No. 161).

Spodek, B. (1965). Poverty, education, and the young child. Educational Leadership, 22(8), 593-604.

Spodek, B. (1978). Teaching in the early years (2nd ed.). Englewood Cliffs, NJ: Prentice-Hall.

Stearns, M. S. (1970, August). Early education: Still in its infancy. American Education, 6 , 3-5.

U.S. Department of Health and Human Services. (1983). Head Start: A child development program. Washington, D.C.: HHS. 
USOE starts push for model schools in urban slums. (1968, June). Nation's Schools, 81(6), 22-23.

Weber, E. (1969). The kindergarten: Its encounter with educational thought in America. New York: Teacher's College Press, Teacher's College, Columbia University.

Winter, L. E. (1963, September). Report to The Committee on Race and Education. Portland: PPS. Verbal report. 
APPENDICES 


\section{APPENDIX A}

\section{EARLY CHILDHOOD EDUCATION IN CALIFORNIA}

Superintendent Wilson Riles gave the Task Force on Early Childhood Education the responsibility of developing a comprehensive, integrated master plan for Early Childhood Education, and on November 26, 1971, the task force submitted to the superintendent a report on its efforts in this area. The basic principles and philosophy of the task force, as expressed in that report, are as follows:

The past decade has produced a new body of educational, psychological, and medical research documenting the crucial importance of the first eight years of life. And we (the task force) are convinced that these early years are critical in determining the future effectiveness of our citizens and in the long-range prevention of crime, poverty, drug addiction, malnutrition, neurosis, and violence. Even though research is still in progress and conclusions continue to evolve, we believe there is enough evidence to indicate that the following are clearly warranted now:

1. The people of the state of California must make a long-range commitment of funds to the proposition that the first eight years of life are the most important in determining the future effectiveness of all our citizens.

2. Implicit in this commitment is the recognition of the desirability of providing equal educational opportunities for all children. Certainly every child aged four through eight, regardless of his environmental, emotional and physical needs, should be included in this recognition. Programs must provide for identifying these needs, for ways of meeting them, and for means of assessing and reassessing program effectiveness. Since it is clear that early diagnosis, intervention, and prevention are dependent upon a close liaison among educational, social, and health services, a cooperative, working relationship among persons in these fields is vital. 
3. School should be a happy place, a stimulating environment in which children can make continuous progress, in which they will want to learn, and in which they can achieve success, both personal and academic. In order to make the early years of learning truly effective, assessment of appropriate and significant developmental levels must be the basis for planning the educational program for each child. If and when needed, corrective social, medical, and psychological facilities must be made accessible to permit the young individual to reach his full potential.

4. Because we recognize the importance of parents in the education of their children, we strongly affirm that parent education and involvement must be an integral part of all Early Childhood Education Programs. Parents should be included in both the planning and evaluation of individualized instruction for their children.

5. There must be encouragement of local autonomy and creativity in program development, with provision for maximum flexibility within broad state guidelines. School districts and other agencies involved in the programs must be allowed freedom to experiment and individualize to meet the needs of the children they serve.

6. Accordingly, then, we believe it is essential that California establish at once for primary children a broadly based educational program that includes children at least one year younger than those beginning school now. This proposal will require school districts to restructure and expand existing programs in order to bring about the maximum development of every child aged four through eight. Implicit in this proposal, too, is the recognition that the individual child is the unique recipient of instruction. We therefore believe the present large group approach to the education of primary children must change significantly in order to make possible the necessary personalized instruction.

Given this mandate from the Task Force on Early Childhood Education, the Department of Education has developed a plan to implement the intent of the task force report. The plan is set forth in two parts. 
Part one of this plan is a narrative description that sets forth the goals, program considerations, and alternatives to be considered by each school district in developing a master plan for Early Chilahood Education.

The plan for Early Childhood Education has as its goal the restructuring of primary education for California's public school children. The program for young learners from four through eight years of age does not suggest "more of the same" or "pushing kindergarten downward." It provides for a system of public education that offers "access to

success" to all children. This system will be designed to provide all children with the opportunity and the motivation to attain mastery of skills that are basic to their academic and personal achievement in school and in life. It is important to note that the plan stipulates that school attendance of the child will remain optional until age six. However, it is intended that in the near future an approvable program will be offered to all children whose parents wish them to attend public school at age four.

The proposal plan attempts to capture the imagination, talents, motivations, and commitments of communities and their lay and professional representatives in the following ways:

1. By recognizing that the greatest potential for the success of the new primary school program rests with persons within communities and school districts who are earnestly willing to address themselves to the educational needs of young children and who are willing to commit their talents and energy to the development of Early Childhood Education programs appropriate to the specific needs of children in their communities.

2. By offering priority funding to districts that have most effectively addressed themselves to local needs.

3. By offering an expansion of funding on a planned sequential basis to those districts that have directed their resources and energies to the development, implementation, and demonstration of program excellence based on locally developed program objectives that reflect the characteristics of the communities concerned. 
4. By providing opportunity to demonstrate that public education is at its best when it is held accountable for meeting the needs of communities and when it is rewarded for success in this area.

Part two of the plan is a detailed description of the financial resources to be allocated to the Early Childhood Education programs, a strategy for funding school districts, and legislative proposals to expedite the intent of the plan, as follows:

1. The Department of Education will reorganize the existing application procedures for all appropriate federal and state funds to guarantee that highest priority be given to Early Childhood Education.

2. State Board of Education guidelines will require that all school districts ensure the coordination and concentration of all appropriate federal and local resources to implement the intent of the program being submitted for approval.

3. High priority for program approval and funding under State Board of Education guidelines will be granted to those school districts that have demonstrated coordination, concentration, and redirection of all appropriate financial and human resources to implement their programs.

4. Financial resources will provide an opportunity for a new type of public education for all children who attain the age of three years and nine months as of september 1 of the current school year.

5. Financial resources will provide for a comprehensive, articulated and expanded educational opportunity designed to provide each fourthrough eight-year-old child with "access to success" based upon his unique interests, talents, and capacities.

6. Additional financial resources will be provided to expand programs and provide services to children from low-income families. 
7. During the phase-in period, grants will be made only for the benefit of those pupils who are included in programs that are operating in accordance with an approved plan.

8. An evaluation program will be established to monitor and review programs systematically. Local expansion will be authorized only after substantial achievement of initial program objectives has been demonstrated.

9. Legislation will be prepared to stipulate that approval of a district's program design and application under state Board of Education guidelines will constitute a waiver of specific constraints set forth in the Education Code and in the California Administrative Code, Title 5. 


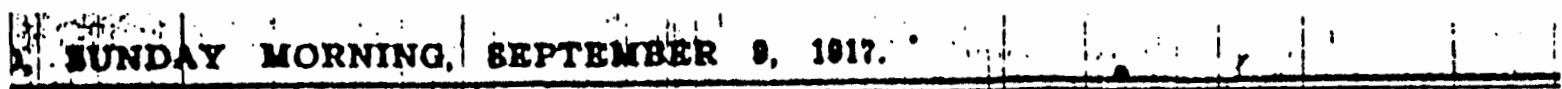
Kindergartens Opened in
Three Portland Schools

Innovation in Public School System Established Last Week -Outlook Favorable for Success of This Feature of Child Training.

otderably Jarger. Iullins racbles os und cect ucoecdine day ading mort chilarea. Osir 10 ibliarea can be cerved tor el one tine oy the ceappor and hor enetetent, heave it al read hes bean found beopieners to bave both

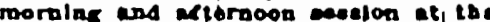
Enalline echool

The novelfy of the linderiarted developel mally unooked for problame for both locutine and ohllarm. I any of the llttle lonee wer broughe by thete motbera the tiret der, but come who came umeccompanied. wert o awed thet thelr little tangue eleared to the roofe of thelr mouth and they were undole lo opeak word. vien unolr anones and erees on the stret any. bome etabd encertered moting ebur llede vinirta und a cobelood one was o orereorn. that ib tan wellod to the wurfuce end rolled lown nushed chedie for no romeon in the topla and alhere pare unablo to tlod thelr rey bome weac But this wea enly rde the plrot lay.

The teabors are il tresed kinder

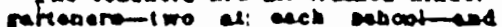

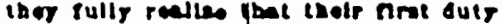
L to win the lor and connderos of thelr llitle pupile and bafore ine reok

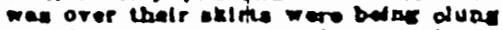

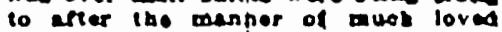
mothore end thelr' wond of laforme. then and onterefinment were lwened to vith elomet difention a lear for - der marate le 1 time.

The abinty of $\bar{b}$ oblla betron the

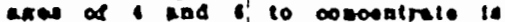
nelurally uoiled." eld Mre. Holler "Thase thelr oocupecion muet be obened Irdueney if inelr laterex lo $10 \mathrm{~m}$ hold. Wo are come whet handlosposes by lack of rquioment thees flrot for

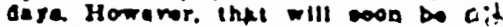
Jieted Thon too. Li. corollmeat is 0 wub lerer. than antlalpeted thet

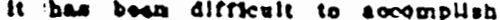
much onell the marola us anersoon eovions boome a realley.

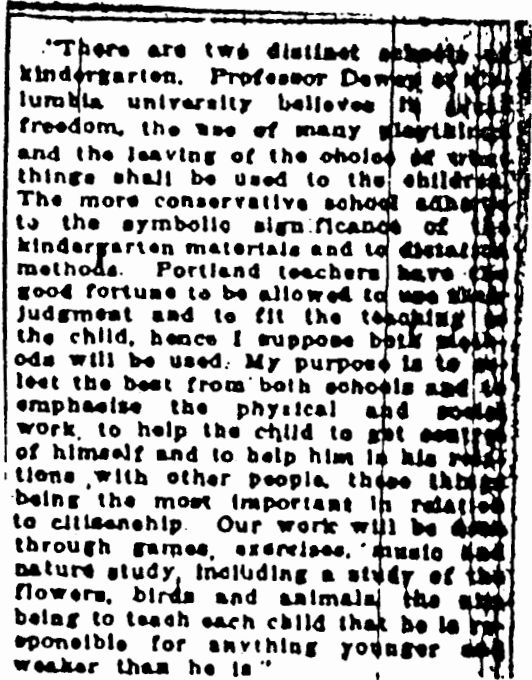


Third Column (not clear on copy)

"There are two distinct schools of kindergarten. Professor Dewey of Columbia believes in much freedom, the use of many playthings and the leaving of the choice of what things shall be used to the children. The more conservative school adheres to the symbolic significance of the kindergarten materials and to dictation methods. Portland teachers have the good fortune to be allowed to use their judgement and to fit the teaching to the child, hence, I suppose both methods will be used. My purpose is to select the best from both schools and to emphasize the physical and social work to help the child to get control of himself and to help him in his relations with other people, these things being the most important in relation to citizenship. Out work will be done through games, exercises, music and nature study, including a study of the flowers, birds and animals, the aim being to teach each child that he is responsible for anything younger and weaker than he is." 


\section{APPENDIX C}

\section{KINDERGARTENS: CITATIONS IN LOCAL NEWSPAPERS}

1. Entertainment given for benefit of Portland Free Kindergartens. Brief sketch of their organization. Oregonian $5 \mathrm{~N} 1885 \quad 5: 1$

2. Free kindergarten association holds annual meeting. The Superintendent's report of work done during the past year. Oregonian 21 Ap $1886 \quad 3: 4$

3. Communication by Secretary. Portland Free Kindergarten. Need of a piano. Methods used. Oregonian $1251886 \quad 8: 1$

4. Editorial. The kindergarten proposition. Oregonian $4 \mathrm{Mr} 1887 \quad 2: 1$

5. Annual meeting of the Portland Free Kindergarten Association held. Work of the year reviewed by Superintendent. Oregonian 20 Ap $1887 \quad 4: 1$

6. Annual meeting of the Free Kindergarten Association. Report of past year's work. Oregonian 18 Ap 1888 8: [sic]

7. Report of Superintendent of the Portland Free Kindergarten, at annual meeting. Oregonian 21 Ap 1890 $5: 3$

8. Portland Free Kindergarten Association holds meeting. Oregonian 19 Ap $1893 \quad 6: 5$

9. Graduation exercises of Oregon Kindergarten training school. Oregonian $28 \mathrm{Je} 18934: 6$

10. Communication by Mary H. Cartwright. Plea that kindergartens become a part of the public school system. Oregonian 8 My 1897 8:4

11. Free Kindergarten Association holds annual meeting. Oregonian 16 My 1900 10:4 
12. Work of Portland kindergarten. Oregonian $11 \mathrm{Mr} 1902$ $10: 1$

Citations taken from oregonian Index, 1850-1909, State and Local Affairs, compiled by University of Oregon. Available on microfilm at Library Association of Portland main branch library and the oregon Historical Society library.

13. No election to be held re kindergarten. Oregonian 18 Ag 1915 11:

14. \$144,165 cut from school budget; kindergarten proposal eliminated. Oregonian $4 \mathrm{~N} 1915$ 5:

15. Lockwood investigates kindergartens. Oregonian 16 N 1915 7:

16. International Kindergarten Union address by Mrs. orvill Bright. Oregonian 4 My 1916 3:

Citations taken from Oregonian Index. Compiled and published by The oregonian in book form. Available at Oregon Historical Society and on microform at Library Association of Portland. The University of Washington Suzallo Library has a more complete set.

17. Need of public kindergartens in Portland. Telegram 18 S 1913 20:

18. Many urge the establishment of kindergartens in connection with the public schools. Telegram 26 Ap 1915 7:

19. Voters to decide on kindergarten question. September 1. Journal 14 Ag 1915 5: Oregonian $14 \overline{\mathrm{Ag} 1915}$ 12:

20. School board rescinds action on kindergartens. Journal $18 \mathrm{Ag} 1915$ 14: Telegram $18 \mathrm{Ag} 1915$ 8: Oregonian $18 \mathrm{Ag} 1915$ 11:

21. Kindergarten plan is costly. Oregonian $16 \mathrm{~N} 1915$ 7: [date unclear] 
22. Kindergartens to open in three public schools. Journal 9 S 1917 (3) 9:

23. Kindergarten to open. Oregonian $28 \mathrm{Ja} 1929$ 18:

24. Schools drop kindergarten. Oregonian 23 Ag 1946 1:

Citations taken from newspaper index on fiche at Library Association of Portland main branch and other libraries. Citations complied by staff of Library Association of. Portland.

A recommendation in favor of the establishment of kindergartens in Portland appeared on pages 154-156 of the Report of the Survey of the Portland School System of School

District No. I, Multnomah County, Oregon: Report of the Committee Appointed at the Taxpayers Meeting, Held on December 27, 1912.

This is available at the Oregon Historical Society library: 379.7911 P852C 


\section{APPENDIX D}

\section{THE KAISER CHILD SERVICES*}

The centers which were operated by the Kaiser Shipbuilding Corporation during World War Ii were unusual enough to warrant description at some length. The idea that the shipyards provide child care originated with Edgar F. Kaiser, the son of Henry J. Kaiser. Two centers were opened, one at the Swan Island Shipyard and one at the Oregon Shipbuilding Corporation, both in Portland, Oregon. The centers were located directly at the entrance to each shipyard, differentiating them from other federally supported day care centers located throughout the Portland community. They were managed as a department within the industrial company. The centers opened November 8, 1943 and closed September 1, 1945.

Enrollment: Children were enrolled from eighteen months of age to six years of age. On Saturdays, sundays, and school holidays the Centers also provided care for school-age children. The Centers were open whenever the shipyards were open--seven days a week, twenty-four hours a day, 364 days a year. Children attended during the shift their mother worked. Day shift and swing shift were equally popular . . Graveyard shift was an exceedingly small service. It tended to be a temporary arrangement used by parents when their plan for home care broke down, and until they could arrange a new plan.

In the beginning, enrollment was slow to build up, because, although all statistics indicated large numbers of children, each family had obviously already made a plan of some kind if the mother was employed. Only Kaiser employees were eligible; and after the centers began to be known, there were instances of people seeking work at the shipyards in order to get the excellent child care. From a very small, slow beginning enrollment, the figures quickly mounted in the first six months of operation until a peak

Gwen Morgan, "The Kaiser Child Service Centers, in A Proposal to Establish a Work-Related Child Development Center, pp. 68-74, mimeographed 1967, used with permission of the author. 
attendance of over one thousand was reached in the first year. The centers served 4,014, different children, many of them not regularly enrolled.

Staff: Each center had a director, and fully qualified teachers and assistant teachers for each group of children. In addition to the educational staff, each had a trained social worker, a nursing staff, and a chief nutritionist.

A total of 292 professionals were employed at the Centers during the twenty-two month period. Teachers were recruited from all over the nation. A good deal of thought and effort went into personnel policies to assure a low turnover and a friendly atmosphere in which staff members would "feel at ease and free to contribute and to participate." (Final Report) Applicants were sent a prepaid railroad ticket; their train was met; they were helped to find housing; and they were made to feel welcomed into a warm social group from the moment of their arrival. Interstaff memos raised questions, offered help and encouragement.

Every effort was made to keep group size to a reasonable minimum, but there were times when the pressures for the employment of women in the yards temporarily exceeded the supply of trained personnel. There were also times, especially after one layoff at the Swan Island Shipyard, when the centers temporarily had more staff than enroliment warranted.

Costs: The United States Maritime Commission provided buildings and equipment of unusually high quality. Parents paid $\$ 5$ per week for the first child, and $\$ 3.75$ for siblings. Low fees for certain special services brought in a little additional income. The remainder of the budget was paid by the company, whose net costs were $\$ 2.37$ per capita per day. Parents paid only when their children were in attendance, and attendance was roughly eighty percent. Since the building and equipment were provided, the budget went primarily for staff, some eighty-four percent of expenditures. . .

The staff made a serious effort to provide a program of very high quality with the least possible expense. This attempt may have reflected a wartime spirit of cooperation with industry, and it also reflected a pioneering spirit and the expectation that such nursery schools were going to continue in peacetime. "One part of our experiment is to discover whether or not large scale nursery education is 
financially feasible for industries and for communities. This relates to the number of people employed, but also to expenditures for supplies, materials, services, etc." (James L. Hymes, memo)

From a financial point of view, the results of the experiment were inconclusive. According to the Final Report, "A fair conclusion seems to be that, while most expenses incurred in the operation of the two centers were justified by conditions here, it is not correct to assume that another situation will produce identical conditions leading to an equal financial deficit." It was not possible to araw up a final balance sheet on the profit and loss of the operation of the two centers. Against the costs of operation, says the report, must be placed what it has meant to a large number of children to have what was probably the best child care offered in the country. "It probably meant gains to parents and better health and stability for the community and the country." And finally, the report goes on to mention the contribution the centers made in industrial terms, to recruitment, to presentism, to morale on the job, and to public relations. No conclusion is offered about whether the advantages balanced the halfmillion dollar operating costs . .

Relations with the company: A wartime spirit of national cooperation provided optimum conditions for working out a team approach. "The personnel office of the shipyard gave help in publicizing the existence of the centers; posters, loud-speaker announcements and guided tours of the Centers helped in making their existence that the parents of the children enrolled were extremely grateful to the company for both the service provided and for the high quality of the service. I believe the company felt the service to be among its most useful employee benefits." (James I. Hymes, September 1966 letter)

The Centers tried to fit themselves into the shipyards. In one memo, Dr. Hymes says, "We must do our job in integration with industry, rather than parallel to it or isolated from it. One measure of our success, for example, is the extent to which we make known the resources we ourselves represent, and whether we encourage the shipyard to use our professional skills in every way they can be used." Another measure was the school's use of the resources of the company. Dr. Hymes' Final Report recommends that future centers establish closer working relations with the Personnel Office of the company. "One theoretical danger underlies industrial nursery schools, 
that the pressure of industry for workers will lead the school to accept a child, who, in the judgment of the professional staff, cannot benefit by group care. It should be stressed that this pressure was not exerted at any time during the twenty-two month period of operation. - . Meaningful relationships between the administration of the Child Service Centers and the staff of the Personnel Department . . . each engaged in employee relations, could be beneficial in the handling of problems and in the development of positive programs to prevent problems."

There is a good deal of evidence that the relations with the shipyard had an effect on the children. They were proud of the ships they saw going by on the river. The Center published a little booklet of anecdotes about the children in November 1944 called "160,874 Children," which contains a good deal of evidence that the adult world impinged on the child world. One such incident, entitled "Their Shipyard" follows:

Almost since the beginning, the oregon Center has had a group of six- and seven-year-olds on swing shift since few other Centers in Portland care for children this age at night. The six- and seven-yearolds at the oregon Center were taken one day to see movies about the shipyard which are shown at the Induction Auditorium. When they came back to the Center, they covered the entire floor of their playroom with big blocks and made a huge ship. Out of blocks they also made a whirley. In the midst of their building a minor argument came up so that they all stood around talking back and forth. After about five minutes, Larry, remembering Edgar Kaiser's last words in the movie, pushed up his sleeves and said, "Well, I've got to roll up my sleeves and get to work."

- . The attitude of respect for parents and a determination to provide whatever service was needed certainly permeated the philosophy of the Kaiser Centers. It led to a program not conforming to any ideological model, but closely in touch with reality. As time went on, more and more services were added, often for a small fee. In the end these were to comprise a long list.

Besides the special program for preschool children, the Centers were unusual in providing a number of extras: 
--Child Care was offered during three shifts. Older children, too, were sometimes able to attend swing and graveyard shifts if necessary . . .

--Special care was available for nonenrolled children. Parents whose other arrangements for their children temporarily broke down could bring their children on a day-to-day basis. One Center had a special services Room for such children; the other integrated them into the regular groups.

--After school care was given school-age children, also Saturdays, holidays, vacations, including summers.

--Children could stay for an extra shift if their parents needed time for overtime work or any other reason, even if only to attend an occasional movie. Day shift children could stay through swing shift supper.

--The program was flexible to allow for individual differences. This was especially true of course with the eighteen months to three-year-old age group.

--Specially built bathtubs made it easy to bathe children. For some living in trailers, this was an important service.

--Food was provided for the children as needed. For example, breakfast was needed for day shift children, who arrived at 6:15 A.M., so it was served. Whatever meal could not be given the children at home easily, was prepared at the Centers. . .

--Home service food was provided. By ordering in advance, a parent could pick up the evening meal at the Center's kitchen after work.

--Booklets for parents were printed. Informal, unpretentious, and cheerful, these sound, informative pamphlets grew out of discussions at parent meetings, which indicated a need for information on such matters as "Children and War," "Toys to Make," and "Recipes for Foods Children Like."

--Newsletters were also printed, warmly human, letting the parents know more of what their children were doing at school, and news of the staff. 
--Nine booklets for teachers were mimeographed. These grew out of staff discussions and were useful enough to be circulated all over the country.

1. A Social Philosophy from Nursery School Teaching

2. Must Nursery School Teachers Plan?

3. Who Will Need a Postwar Nursery School?

4. Meeting Needs: The War Nursery Approach

5. The Role of the Nutritionist in a War Nursery School

6. Large Groups in the Nursery School

7. Should Children Under Two Be in Nursery School?

--An infirmary for children who were not seriously ill was part of the service. Dr. Hymes recommended that later centers consider an isolation infirmary for children with contagious diseases.

--Diagnostic tests, immunizations, dietary supplements were given as needed.

--Shipyard facilities were used for equipment construction. A carpenter assigned to the Center constructed some play materials especially designed for their use.

--Close relations were maintained with parents in a spirit of service. Teachers, nurse, nutritionist, and family consultant were available and eager to help. Dr. Hymes recommended that in future centers the mothers be encouraged to visit the centers while in operation, especially in the beginning...

--A mending service for mothers was established.

--Shopping service was offered. One shopper did errands for fifty mothers.

--An appointment service was provided. The Centers would make and take children to appointments with dentists, etc. 
--Barbers were brought to the school to give haircuts.

--Shoe laces, panties, and other necessities began to be sold at the Centers.

--Photographers were brought in so that Christmas gifts of photographs could be ordered.

was set up. . . .

--A lending library of books and toys for children

The wartime spirit of sharing in a job to be done is probably something impossible to recapture in another era. But the remarkable feeling of respect for family needs, and for reality, is an important value developed in the Kaiser Centers, which should not be lost.

Results: The Kaiser Centers helped to improve standards in other child care agencies, contributed to the development of programs by those agencies to better meet the particular needs of shipyard workers, and contributed to increased understanding among the public regarding adequate standards for the care of young children. They demonstrated that a nursery school staff can contribute to the morale of workers on the job, and help them to do a better job with their children. They demonstrated that excellent child care facilities can be operated by industry to the great advantage of children and parents and to the benefit of industry. (Final Report) The hope that this was a pioneering effort which would lead to an increase in child care programs and in meeting family needs, however, was never realized. Why did the Kaiser Centers and other day care centers die out after the war? The full answer is probably quite complicated. One part of the reason is that Kaiser Industries and other industries had no further need of the centers in the immediate postwar operations. There was a fire at the Swan Island Shipyards in the late summer of 1945, and the yard never reopened. In September, both yards closed, since the wartime need for ships abruptly stopped, and along with the yards, the Child Service Centers closed their doors.

Their disappearance from the national thinking is quite sudden. During the entire war period there is an element of guilt in the literature which discusses the need for child care to enable mothers to contribute to the war effort. When the war ended, the nation tried to get "back to normal" as quickly as possible, and normal meant that 
the mother was to be in the home bringing up her own children. In some ways, this postwar period tied women more closely to their homes than they had been before or would be afterward. In spite of the fact that women have been choosing to work in greater and greater numbers during the last few decades, and in spite of the evidence of their economic need to work, the professional fields concerned with children have continued to think of the home-centered mother as the only model for the American family. This may explain why all that was learned in the Kaiser Centers suddenly dropped from sight. The nation, guilty over the war experience, and seeking other values, did not want to hear about the values of the wartime child care experience.

"Another reason, almost surely was the cost." (James L. Hymes, September 1966 letter) The Kaiser Centers were of very high quality and they were expensive. Even with the initial help of the Maritime Commission, the Kaiser shipyard was paying a very high operating cost. This was possible in wartime, when the company was motivated by a determination to get the job done. Wartime industries could not be cost conscious; they had to do whatever was necessary. It may be that a nursery school in those unusual times could be considered a legitimate business expenditure under a government cost-plus-fixed-fee contract. If so, the government indirectly subsidized the schools in full. After the war, it was no longer possible for Kaiser or any other company to survive if it provided an employee benefit of this magnitude. The hope was prevalent in the immediate postwar period that if such services continued to be needed, the community would provide them. But costs, instead of going down as expected, have continued to rise.

Whatever the reason, there is little known today of the Kaiser Centers. The results of a remarkable experiment made by an outstanding group of educators have not had the impact on American education, or on the fields of public health and welfare, that they expected them to have. 


\section{APPENDIX E}

\section{SCHWAB COMMITTEE RECOMMENDATIONS}

We, your Committee on Race and Education, have in this Report discussed what we feel is this community's most serious problem. We know that our school system appreciates the problem and is eager to increase the quality of its outstanding contribution to our community. We know that the community in general is eager to enhance its own future through support of its fine schools. It is in this confident spirit that we offer our recommendations to our schools and to our community, and urge their implementation as promptly as feasible consistent with the internal requirements of individual recommendations.

Recommendations Directly Affecting the School system

A. Model School Program

1) We recommend that the Portland school system establish a Model School Program to bring intensive educational efforts to bear on a number of elementary schools. The Model School Program should be created administratively no later than January 1, 1965, and the Model Schools should be operational in September, 1965. The program should be continued for a minimum of six years. Schools originally chosen for this program should be in reasonable geographic proximity. Model Schools should be those in which the achievement levels are significantly below the city-wide mean and which have a high incidence of social and learning problems. We nominate these schools for consideration for inclusion in the program: Eliot, Boise, Highland, Buckman, Holladay, Humboldt, Whitman, George, Woodlawn and Irvington. If it is not possible to include all ten schools originally, those omitted should be brought into the program as rapidly as possible. In any event, no fewer than six of these schools should be included originally, and these six should include at least two predominantly Negro enrollment schools and at least two predominantly white enrollment schools.

2) We recommend that the Model School Program be placed under an Administrator who shall be directly 
responsible to the Superintendent outside the regular administrative organization. The Administrator's status shall be at least equivalent to that of an assistant superintendent. The Administrator shall have charge of the schools placed under the program and shall develop an instructional program, staff assignment and school organization with the assistance of his principals and teachers. Such arrangements shall be shaped to suit the needs of the particular school and shall be likewise designed to produce useful data on the value of innovations employed. The Administrator shall be appointed and shall commence his planning for the program no later than January 1, 1965, and shall be authorized to employ an Assistant Administrator and such additional staff and clerical assistance as he requires.

3) We recommend that the Administrator be supplied with such additional teaching personnel as is necessary to achieve a teacher-pupil ratio within the program of I-20. The Administrator shall fix class sizes and pupil-teacher ratios within schools and among schools in the program as he shall deem necessary in order to meet educational needs and to serve various programs under his supervision.

4) We recommend that within the Model School Program the Administrator be authorized to withdraw all or part of the 7 th and 8 th grade children in Model Schools and establish them in a Model Upper Division Grade School, one objective being to release classrooms to lower class sizes. The Upper Division Model School may be established in a suitable facility such as couch or in a temporary facility. Where children are required to travel more than one mile to the Upper Division Model School, their transportation cost shall be borne by the School District. The Administrator shall likewise be authorized to provide temporary facilities at Model Schools if necessary to accomplish desirable class sizes and provide facilities for special classes.

5) We recommend that a new school be constructed as rapidly as possible to serve as an Upper Division School if desired, or alternatively as an additional elementary school. The new school building should be constructed so it is suitable for either use by the Model School Program, with attendance boundaries adjusted accordingly. The location should be chosen in accordance with Recommendation 18 below.

6) We recommend that a preschool educational program be established in as many of the ten Model Schools we 
nominated as possible to provide experiences which will compensate for deficiencies of disadvantaged children at the time they now enter the regular school program. The preschool program should be established on a voluntary attendance basis to include as large a percentage of children as possible, beginning at age four and preferably at age three, with as long a school day and school year as possible. Consideration should be given to the possible favorable psychological effects of charging a nominal fee, but in any case the major costs should be met at public expense. Special emphasis should be placed on careful statistical analysis of the later performance of preschool program children in comparison with carefully selected controls. We further recommend that, in addition to its own administration of special preschool programs, the School District encourage and co-operate with the private preschool programs being undertaken by several organizations in this city.

7) We recommend that additional funds be provided the principal of each Model School to be used at his discretion for supplementary materials, for transportation of classes on exchange visits and expeditions to enlarge the experience of the children. We also recommend that the Administrator be authorized to re-establish competently staffed individual libraries in schools of the Model Program and to allow them to remain open and staffed after regular hours and during vacations. We also recommend that the Administrator be authorized to use and to experiment with the use of parents and high school and college volunteers to assist in regular and extra-curricular activities, studies and programs.

8) We recommend that the Administrator be authorized to select personnel for his Model Schools as he shall deem necessary. The Administrator should be encouraged to interview principals and teachers in the system to fill vacancies in the Model School Program and his principals should be authorized with his approval to transfer teachers out of the program when they shall deem it necessary.

9) We recommend provision of a full time nurse for each school in the Model School Program; in addition, each Model School should have a full time community agent to assist the principal in planning after-school and evening activities for children and parents, and developing the attendance area's participation in and support for educational improvement. A full time clinical psychologist adequately trained in testing procedures and a psychiatric 
social worker should be attached to the Administrator's staff.

10) We recommend that the special achievement program as applied to the Model Schools be placed entirely under the supervision of the Administrator.

11) We recommend that in Model Schools, including the Upper Division School, where EE courses or classes are not available for qualified students, that such students be sent part time to attend classes inother schools where such courses are available. Transportation will be paid by the schools. Arrangements for this shall be made by principals of Model Schools with principals of other schools with the approval of the Administrator. Students so selected should be placed in schools where their experience and that of their fellow students will be enlarged by such placement.

12) We recommend that when in the judgment of the Administrator and his staff the education of any child in the Model School program would be materially improved by transfer to another school in the Portland system, such child shall be transferred provided the parents consent and provided no serious crowding exists in the school to which such child is transferred. Transportation costs shall be provided by the schools. Students so selected shall be placed in schools where their experiences and that of their fellow students will be benefited.

13) We recommend that teachers to be assigned to the Model Schools be given an intensive course during the summer of 1965. Teachers attending the course should receive compensation for the time spent in attendance. The course should encompass the goals of the program and the techniques successfully employed in similar schools. In addition, such programs should be continued in future years for newly assigned teachers. Likewise, the Administrator should be authorized to establish in-service training programs during the regular year to introduce new techniques and to evaluate existing programs.

14) We recommend that the Administrator be authorized to develop programs and procedures to give recognition to teaching excellence and to encourage the development of esprit among teachers, administrative personnel and students. 
15) We recommend that the Administrator be authorized to enter formal and informal co-operative arrangements with metropolitan colleges and universities which desire to co-operate in the Model School Program, provided that the Administrator shall retain full authority, supervision and responsibility for such arrangements and may terminate them at his discretion. 